\title{
Transformational Leadership Style on Nursing Job Satisfaction Amongst Nurses in Hospital Settings: Findings From Systematic Review
}

\author{
Saleh Alzahrani ${ }^{1}$ \& Abd Alhadi Hasan ${ }^{2}$ \\ ${ }^{1}$ Clinical Nurse Manager, Makkah, King Faisal Hospital, Jeddah, Kingdom Saudi Arabia \\ ${ }^{2}$ Fakeeh College for Medical Sciences, Jeddah, Saudi Arabi \\ Correspondence: Abd Alhadi Hasan, Fakeeh College for Medical Sciences, Alhamra district, Palestine Street, \\ Jeddah, Saudi Arabia. Tel: 966-53-640-6602; Fax: 966-547-654-3216. E-mail: aalhasan@fakeeh.care
}

\author{
Received: March 18, 2019 Accepted: April 18, 2019 Online Published: April 24, 2019 \\ doi:10.5539/gjhs.v11n6p25 URL: https://oi.org/10.5539/gjhs.v11n6p25
}

\begin{abstract}
Background: The nursing shortage is a common problem in Saudi Arabia with multi-factorial causes. In addition to the low supply of Saudi graduate nurses from training facilities, job satisfaction remains a significant determinant of nurse turnover and intention to leave that contribute to the shortage of nursing workforce. The higher number of expatriate nurses who have a short stay compared to Saudi nurses compounds this problem. Therefore, effective strategies for making the nursing profession attractive and increasing nurse retention in Saudi Arabia are required.
\end{abstract}

Objective: The general objective was to examine the impact of transformational leadership style on job satisfaction amongst nurses in hospital settings. Specifically, the appraisal examined how transformational leadership style improves nursing job satisfaction in hospital settings, determined the mediating factors of the relationship between transformational leadership style and nurses' job satisfaction, and investigated nurses' perceptions of transformational leadership style compared with other leadership styles.

Methodology: This study was used systematic review design with eight selected quantitative nursing research published between 2012 and 2017. A systematic search of the recent literature was conducted on PubMed, Scopus, Wiley Online, and Web of Science databases using search terms developed a priori to identify the articles that met the inclusion criteria. The quality of the included studies was evaluated by McMaster Critical Review Form for Quantitative Studies. Extracted data were summarised, explored and correlated using narrative synthesis.

Findings: Eight studies of cross-sectional design were appraised. Transformational leadership style was positively related to nurses' job satisfaction. Transactional leadership also had a positive correlation while passive-avoidant or laissez-faire style had a negative relationship. Transformational leadership improved nursing job satisfaction through its dimensions (idealised influence, inspirational motivation, intellectual stimulation and individualised consideration). Nurse empowerment and workplace support mediated the relationship between transformational leadership and nurse job satisfaction. Nurses had a higher perception of transformational style compared to other leadership styles, and job satisfaction was found to improve nurse and patient outcomes.

Conclusion: Transformational leadership appears to improve job satisfaction of nurses working in a hospital setting that leads to higher nursing retention. Hospital administrators and managers should practice transformational leadership to improve job satisfaction of staff nurses for better nursing outcomes, and leadership skills should be incorporated in the nursing education curriculum. However, further evaluation of transformational leadership in relation to its influencing factors is required.

Keywords: leadership style, job satisfaction, empowerment

\section{Background}

Transformational leadership is one of the leadership styles that Braun et al. (2013) defined as a leadership approach that leads to change in individuals and the social systems whereby the followers develop to become leaders. Bucic et al. (2010) noted that transformational leadership style is suitable in dynamic, and adaptive and progressive learning environment. Similar to the nature of hospital settings, transformational leadership can therefore be useful 
in these kinds of environments to improve nurses' job satisfaction. Job satisfaction has been studied extensively as a concept due to its potential impacts and influence on organisational and employee-related outcomes such as productivity, attrition rates and retention (Eslami and Gharakhan, 2017). A more general and broader view of job satisfaction includes both the "satisfaction" and "dissatisfaction" in relation to one's job. As a result, Spector (1997) defined job satisfaction as "the extent to which people like (satisfaction) or dislike (dissatisfaction) their jobs." The most commonly used definition of job satisfaction is Edwin Locke's that refers job satisfaction as "a pleasurable or positive emotional state resulting from the appraisal of one's job or job experience" (Locke, 1969). However, job satisfaction has cross-cutting definitions going beyond the positive feelings that are usually perceived as the only determinants of how individuals view and relate to their jobs. Therefore, the definition of job satisfaction should also involve factors or measures of negative feelings like work pressure that may affect individual-work relationships. A concept analysis of published nursing literature by Castaneda and Scanlan (2014) identified three key attributes of job satisfaction in nursing including autonomy, interpersonal relationships, and patient care. As a result, job satisfaction in nursing can be defined as the extent to which nurses are satisfied or dissatisfied with their work in relation to these attributes. Even though job satisfaction in healthcare specifically nursing in a hospital setting can be identified and measured, this definition is mainly an affective reaction to a job resulting from the comparison of actual with the desired, expected and deserved outcomes.

\section{Transformational Leadership Factors}

Transformational leadership is characterised by four dimensions including idealised influence, inspirational motivation, intellectual stimulation, and individual consideration (Avolio, 2011).

\subsection{Idealised Attributes}

Idealised attributes of transformational leadership that can be attributed or behavioural enhance leadership authenticity and level of credibility and acts as a role model for high standards of ethical behaviour, pride, and respect and trust among the employees (Bass and Riggio, 2006; Kanste et al., 2009; Avolio, 2011). It results in the emulation and identification with the leader's behaviour, moral and ethical values as well as sharing and commitment to the common goals and development of high levels of trust (Bass and Riggio, 2006). However, hierarchical organisational regulations that constrain the followers and limit their innovative ability can render this attribute ineffective as the employees to continue to meet their leader's expectations (Bruch and Walter, 2007).

\subsection{Inspirational Motivation}

Leaders with inspirational motivation create a clear sense of purpose and act as role model for their followers to realise their vision with charisma, enthusiasm, and optimism (Kanste et al., 2009; Avolio, 2011; Giltinane, 2013). Moreover, with the use of effective communication, leaders set high standards and encourage their followers to fully exploit their ability to achieve them (Avolio, 2011; Bass and Riggio, 2006). Kanste et al. (2009) and Avolio (2011) also observed that it is the clear sense of purpose and meaning, and visionary leadership as well as appealing and inspiring articulated vision that would motivate the employees to act. As a result, the employees become inspired to chat own leadership path promoting personal gratification and satisfaction.

\subsection{Intellectual Stimulation}

This characteristic of transformational leadership refers to the degree of challenging assumptions, taking risks and soliciting ideas whereby leaders encourage their followers to question the norms, to think and to come up with new ideas for improvement; thus, promoting creativity, independent thinking, and innovation (Bass and Riggio, 2006). With uncommon situations considered an opportunity to learn, leaders who demonstrate intellectual stimulation encourage creativity, nurture and develop individuals who can think independently to find better ways of doing tasks (Avolio et al., 1999; Bass and Riggio, 2006; Avolio, 2011).

\subsection{Factors Influencing Nurse Job Satisfaction}

There are many and varied factors influencing intrinsic or extrinsic job satisfaction of the motivation-hygiene theory (Herzberg et al., 2008). As noted by Atefi et al. (2014), they can be categorised into three groups, including work environment, motivation, and personal belief factors.

\subsection{Work Environment Factors}

The influence of work environment on job satisfaction and dissatisfaction was investigated in focus group discussions of 85 critical care and medical-surgical nurses by Atefi et al. (2014) where the authors found team support to increase nurse job satisfaction. Similarly, Asegid et al. (2014) in a mixed design cross-sectional study found group cohesion to positive influence nursing job satisfaction. Atefi et al. (2014) also found poor leadership skills, working conditions, lack or inadequate medical resources, unclear nurses' responsibilities, poor patient and 
doctor perceptions, work discrimination, and benefits and rewards to be associated with nurses' job dissatisfaction. Al-Dossary et al. (2012) and Asegid et al. (2014) also found salaries, benefits and contingent rewards for instance as significant factors of nurses' job dissatisfaction.

Even though Atefi et al. (2014) employed a small sample that is appropriate for qualitative designs, it may affect the generalisability of the findings. Together with Asegid et al. (2014), it may also not apply to Saudi setting due to their different cultural and practice contexts from Saudi's as well as the cross-sectional design that limits their ability to show causal relationships between the variables.

The role of nurse working units also appears to play a role in job satisfaction. In a cross-sectional study in involving 178 nurses, Kaddourah et al. (2013) found nurses employed in critical care units to be significantly more satisfied than nurses in medical and surgical units due to good orientation programme and competent staff. Similarly, Shang et al. (2013) found oncology nurses to show more job satisfaction compared to medical or surgical ward nurses while Asegid et al. (2014) reported seven times more satisfaction among maternity unit nurses than medical unit colleagues.

The variation in job satisfaction in different hospital units could be attributed to various environment factors such as effective leadership and team support, clear responsibilities, and good working relationships. As a result, nurse managers should have leadership skills to improve work environment to increase nursing job satisfaction and reduce intention to leave and burnout as noted by Nantsupawat et al. (2017).

\subsection{Motivation Factors}

Factors of motivation can also influence nursing job satisfaction. As noted by Atefi et al. (2014), task requirement involving too much paperwork and lack of opportunity and support for personal and professional development as well as clinical autonomy were associated with nurses' job dissatisfaction. Since opportunities such as continuing education and training promote growth and job satisfaction, their absence can lead to higher levels of job dissatisfaction (Asegid et al., 2014; Atefi et al., 2015).Nurse recognition for the job well done has also been found to be a crucial determinant of nurse job satisfaction (Asegid et al., 2014). In a web-based, cross-sectional explorative study, Sveinsdóttir et al. (2016) found praise of staff nurses by nurse managers to result to more job satisfaction. Praise was also associated with more opportunities for professional practice, positive work environment, and organisational commitment as well as valuing professional recognition by nurses. Even though praise seems to play a significant role in enhancing nurses' job satisfaction, it is surprising that it is rarely used with Sveinsdóttir et al. (2016) noting that only $31.6 \%$ of the nurses reported having received praise more often.

\section{Methods}

\subsection{Literature Search Strategy}

According to Greenhalgh and Peacock (2005), an effective search strategy should allow for obtaining as many articles as possible while ensuring attainment of the highest quality of evidence. Therefore, the search strategy employed in this study was designed to find all the quantitative studies that addressed the research question. The literature search was done in four electronic databases, including Scopus, Web of Science, PubMed, and Wiley Online and the hits obtained, and the potentially relevant studies recorded and documented. It was surprising that related articles were not found in CINAHL database probably due to its focus on practice rather than management.

The search terms and the combination list were finally generated in a seven-stage process outlined by Bettany-Saltikov and McSherry (2016) that increases sensitivity, precision, and specificity. The stages included breaking down the research question into its PICO components, identifying the keywords and words using the PICO groups, identifying the synonyms of the search terms, using the Boolean operators (OR and AND) to combine the keywords and phrases, identifying abbreviations, constructing a search strategy table, and finally translating into a search terms and combination list. According to Khan et al. (2011), the sensitivity of the search is a reflection of the comprehensiveness of the search and is determined by the proportion of relevant studies and is higher when the synonyms of the component terms are used. Similarly, the use of Boolean operators and applying limits is critical for determination of the precision of the search, which is the percentage of the number of relevant studies to all studies identified. Some of the search terms were also truncated using the truncation sign $(*)$ to help the database extract studies containing different spellings of the keywords (Greenhalgh, 2014).

Various advanced search reading and tutorial resources were helpful in this process (NCBI, 2013; Web of Science Training, 2014; "PMC Help", 2016; UTS Library, 2017; Elsevier, and; web of Science, and; Wiley Online Library, and). The included studies were selected based on pre-determined eligibility criteria and evaluated by a quality assessment tool known as McMaster Critical Review Form for Quantitative Studies (Law et al., 1998a). A PRISMA flow diagram was used to narrow down search results and to present the included articles as shown in 
Figure 1.

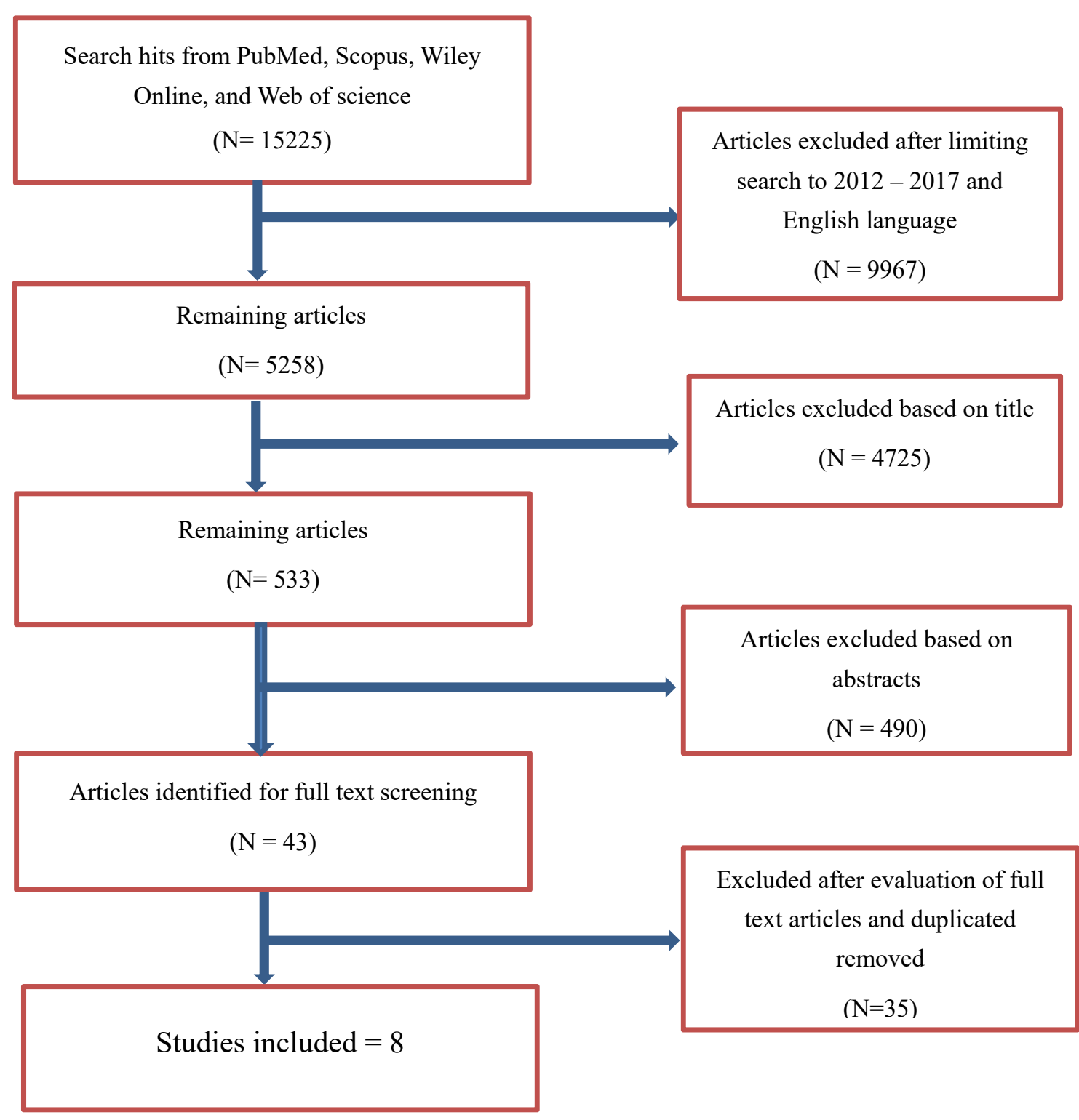

Figure 1. PRISMA Flow Diagram for Study Selection Process

Due to lack of the researcher experience to do systematic searching practice. Therefore, a literature searching conducted two times to avoid missing related studies; the final one was on 15th August 2017 on the four databases with the search terms. Table 1 below gives a summary of the number of hits obtained from the individual database search.

Table 1. Hits from the databases

\begin{tabular}{ll}
\hline Database & Number of hits with unlimited database \\
\hline PubMed & 3,330 \\
Scopus & 3,596 \\
Wiley Online & 4,398 \\
Web of Science & 3,901 \\
Total & 15,225 \\
\hline
\end{tabular}




\subsection{Inclusion and Exclusion Criteria}

The inclusion and exclusion criteria shown in Table 2 was based on PICO elements to eliminate bias in selecting the studies for this appraisal. According to Higgins and Green (2008), the use of inclusion and exclusion criteria is important when conducting a systematic review. Coughlan et al. (2013) also emphasised that the use of selection criteria would help narrow the search of studies and ensure that only relevant articles are included in the review.

Inclusion criteria: Only primary quantitative studies that evaluated transformational leadership as single style or compared with other styles to determine their influence on job satisfaction among nurses in the hospital setting published 2012 - 2017 were included. Moreover, they had to be English and peer-reviewed. Even though the focus was to find only studies conducted in Saudi Arabia, they were limited in number leading to the inclusion of those conducted in other countries.

Exclusion criteria: Non-quantitative or mixed method studies, as well as secondary researches and other sources outlined in the table of inclusion and exclusion criteria, were excluded.

Table 2. Inclusion and Exclusion Criteria

\begin{tabular}{|c|c|c|c|}
\hline Inclusion & Inclusion & Exclusion & Reason \\
\hline Population & Nurses & $\begin{array}{l}\text { Other health care professionals or } \\
\text { mixed with nurses } \\
\text { Setting: non-hospital }\end{array}$ & To answer the research question \\
\hline Setting & Hospital & Other setting & $\begin{array}{l}\text { To minimize bias by eliminating the } \\
\text { influence of factors like workload that } \\
\text { vary between hospital setting and other } \\
\text { work environments }\end{array}$ \\
\hline Country & $\begin{array}{l}\text { Saudi Arabia and other } \\
\text { countries }\end{array}$ & - & $\begin{array}{l}\text { Limited studies in Saudi Arabia to meet } \\
\text { the required 6-12 for this dissertation. }\end{array}$ \\
\hline Intervention & $\begin{array}{l}\text { Transformational } \\
\text { leadership style }\end{array}$ & $\begin{array}{l}\text { Non-transformational leadership } \\
\text { styles }\end{array}$ & To answer the research question \\
\hline Comparison & $\begin{array}{l}\text { Transformational } \\
\text { leadership as single } \\
\text { style but if not } \\
\text { applicable, compared } \\
\text { with transactional and } \\
\text { laissez-faire styles }\end{array}$ & Other leadership styles & $\begin{array}{l}\text { To emphasise the evidence through } \\
\text { comparison of transformational with } \\
\text { transactional and laissez faire leadership } \\
\text { styles, to meet requirement for this } \\
\text { dissertation (6-12 articles) (Northumbria } \\
\text { University, 2017) }\end{array}$ \\
\hline Outcome & Nurse job satisfaction & - & To answer the research question \\
\hline Study design & Quantitative & Qualitative or mixed-methods & To answer the research question \\
\hline $\begin{array}{l}\text { Publication } \\
\text { language }\end{array}$ & English articles & Non-English articles & $\begin{array}{l}\text { Regulation by the Northumbria University } \\
\text { and to avoid potential error from } \\
\text { translation and bias (Northumbria } \\
\text { University, 2017) }\end{array}$ \\
\hline Publication date & Published $2012-2017$ & Published before 2012 & To find the most recent evidence \\
\hline Peer review & $\begin{array}{l}\text { Peer-reviewed primary } \\
\text { articles }\end{array}$ & $\begin{array}{l}\text { Non-peer reviewed, secondary } \\
\text { articles, practice guidelines and } \\
\text { policies, reviews, conference } \\
\text { papers, personal opinions, } \\
\text { commentaries, seminars, and } \\
\text { editorials }\end{array}$ & $\begin{array}{l}\text { To obtain high quality papers and } \\
\text { replication of data }\end{array}$ \\
\hline
\end{tabular}

\subsection{Search Results}

The unlimited databases search resulted in a total of 15,225 records. Limiting the search to English publications between 2012 and 2017 excluded 9,967 papers. Of the remaining 5258, further 4725 papers were excluded after reading the titles. Another 490 were dropped after reading the abstracts of the remaining 533 articles. Subsequently, 43 papers were retrieved for full-text screening that led to the dropping of further 35 articles due to duplicated 
articles and not met inclusion criteria. The remaining eight articles highlighted below were evaluated by McMaster tool and finally included in this critical appraisal as they were of high quality as described in Figure 1.

In line with the research objectives, Abdelhafiz et al. (2015) evaluated the impact of transformational, transactional and passive-avoidant leadership styles on job satisfaction in both public hospital and private hospital settings. The influence of transformational and transactional leadership styles on job satisfaction was compared in four studies (Abualrub and Alghamdi (2012; Bormann and Abrahamson, 2014; Alshahrani and Baig, 2016; Nequssie and Demissie, 2017) while Wang et al. (2012) focused on transformational leadership only. Lin et al. (2015) and Choi et al. (2016) examined the mediating role of transformational leadership style through workplace support and empowerment respectively on job satisfaction, thus highlighting the indirect impact of transformational leadership on nurse job satisfaction. In this appraisal, these studies are represented by symbols, S1 to S8 as demonstrated in Table 3.

Table 3. Included Study Symbols

\begin{tabular}{|c|c|c|}
\hline Author(s) and Year & Title & Symbol \\
\hline Abdelhafiz et al. (2015) & $\begin{array}{l}\text { Impact of leadership styles adopted by head nurses on job satisfaction: a comparative } \\
\text { study between governmental and private hospitals in Jordan. }\end{array}$ & $\mathrm{S} 1$ \\
\hline $\begin{array}{l}\text { Abualrub and } \\
\text { Alghamdi (2012) }\end{array}$ & $\begin{array}{l}\text { The impact of leadership styles on nurses' satisfaction and intention to stay among } \\
\text { Saudi nurses. }\end{array}$ & $\mathrm{S} 2$ \\
\hline $\begin{array}{l}\text { Alshahrani and Baig } \\
\text { (2016) }\end{array}$ & $\begin{array}{l}\text { Effect of leadership styles on job satisfaction among critical care nurses in Aseer, Saudi } \\
\text { Arabia }\end{array}$ & $\mathrm{S} 3$ \\
\hline $\begin{array}{l}\text { Bormann and } \\
\text { Abrahamson (2014) }\end{array}$ & $\begin{array}{l}\text { Do staff nurse perceptions of nurse leadership behaviors influence staff nurse job } \\
\text { satisfaction? The case of a hospital applying for Magnet }{ }^{\circledR} \text { designation. }\end{array}$ & S4 \\
\hline Choi et al. (2016) & $\begin{array}{l}\text { Transformational leadership, empowerment, and job satisfaction: the mediating role of } \\
\text { employee empowerment. }\end{array}$ & S5 \\
\hline Lin et al. (2015) & $\begin{array}{l}\text { The influences of nursing transformational leadership style on the quality of nurses' } \\
\text { working lives in Taiwan: a cross-sectional quantitative study. }\end{array}$ & S6 \\
\hline $\begin{array}{l}\text { Nequssie and Demissie } \\
(2017)\end{array}$ & $\begin{array}{l}\text { Relationship between leadership styles of nurse managers and nurses' job satisfaction in } \\
\text { Jimma University Specialized Hospital. }\end{array}$ & S7 \\
\hline Wang et al. (2012) & $\begin{array}{l}\text { Transformational leadership: Effect on the job satisfaction of Registered Nurses in a } \\
\text { hospital in China. }\end{array}$ & S8 \\
\hline
\end{tabular}

According to the Centre for Reviews and Dissemination (2009), assessing study quality is an integral process of critical appraisal and systematic review as it promotes exclusion of studies that do not meet the methodological criteria and stratify the included studies based on the risks of bias (high, low or both), and the criteria of appraising studies should be stated clearly a priori for transparency reasons. In this appraisal, the quality of the studies was evaluated by the McMaster Critical Review Form for Quantitative Studies that was developed by the McMaster University Occupational Therapy Evidence-Based Practice Research Group as quality appraisal tool for quantitative studies (Law et al., 1998a; Law et al., 1998b). It provides a standardised method of assessing study quality. In this appraisal, these elements were used to develop a quality scoring system of 0,1 , and 2 for unmet, partially met and fully met respectively for each item giving a total score of $0-36$ (Table 4). Moreover, items for quality assessment was developed based on McMaster guideline critical review form for quantitative studies (Law et al., 1998b). After quality evaluation, the decision was further made based on the form created by the researcher. 
Table 4. Quality assessment

\begin{tabular}{|c|c|c|c|c|c|c|c|c|}
\hline Items & $\mathrm{S} 1$ & $\mathrm{~S} 2$ & S3 & $\mathrm{S} 4$ & S5 & S6 & S7 & S8 \\
\hline \multicolumn{9}{|l|}{ Criteria } \\
\hline Is peer reviewed? & 2 & 2 & 2 & 2 & 2 & 2 & 2 & 2 \\
\hline Is published in English? & 2 & 2 & 2 & 2 & 2 & 2 & 2 & 2 \\
\hline \multicolumn{9}{|l|}{ Study purpose and design } \\
\hline Was the purpose stated clearly? & 2 & 2 & 2 & 2 & 2 & 2 & 2 & 2 \\
\hline $\begin{array}{l}\text { Was relevant background literature reviewed? Is there theoretical framework or } \\
\text { conceptual model? }\end{array}$ & 1 & 2 & 1 & 2 & 2 & 2 & 1 & 1 \\
\hline Was the design appropriate for the study? & 2 & 2 & 2 & 2 & 2 & 2 & 2 & 2 \\
\hline \multicolumn{9}{|l|}{ Sample } \\
\hline Was sample described in detail? & 2 & 2 & 2 & 2 & 2 & 2 & 2 & 2 \\
\hline Was sample size justified? & 2 & 2 & 2 & 2 & 2 & 1 & 2 & 2 \\
\hline Is informed consent obtained from the sample? & 2 & 2 & 2 & 2 & 2 & 2 & 2 & 2 \\
\hline
\end{tabular}

\section{Outcomes}

Were the outcome measures reliable?

Were the outcome measures valid?

$\begin{array}{llllllll}1 & 1 & 1 & 1 & 2 & 2 & 1 & 2\end{array}$

\section{Intervention}

Was transformational leadership style demonstrated by nurse manager or $\begin{array}{lllllllll}2 & 2 & 2 & 2 & 2 & 2 & 2 & 2\end{array}$ nursing unit leader in hospital setting?

\section{Co-intervention}

Is the hospital not in Magnet journey or magnet hospital?

$\begin{array}{llllllll}2 & 2 & 2 & 0 & 2 & 2 & 2 & 2\end{array}$

\section{Result}

Results were reported in terms of statistical significance?

Were analysis methods appropriate?

Was result report impact of total transformational leadership style on overall job $\quad \begin{array}{lllllllll}1 & 2 & 1 & 2 & 2 & 2 & 1 & 2\end{array}$ satisfaction for nursing based on hospital type?

Did the study report for overall nursing perception for transformational $\begin{array}{lllllllllll}2 & 2 & 2 & 2 & 0 & 2 & 1 & 2\end{array}$ leadership style based on hospital type?

Drop out were reported for incomplete questionnaire?

\section{Conclusion and management implications}

Was conclusion appropriate given study methods and result? Any implication $\begin{array}{lllllllllll}2 & 2 & 1 & 2 & 2 & 2 & 1 & 2\end{array}$ from the study?

\begin{tabular}{|c|c|c|c|c|c|c|c|c|}
\hline Total & 32 & 34 & 31 & 32 & 34 & 34 & 31 & 35 \\
\hline
\end{tabular}

\subsection{Data Extraction and Synthesis}

Data extraction is the process of obtaining necessary information about the characteristics and findings of the included studies while synthesis involves findings collation, combination and summary (CRD, 2009). Data extraction form was used to extract the study details and findings followed by brief comments. Using a narrative approach, the extracted data, including the key findings were then summarised, explored and correlated to present the main themes related to the aims and objectives of this critical appraisal.

\section{Results}

\subsection{Transformational Leadership Style Was Associated With Nursing Job Satisfaction}

All the selected studies found transformational leadership to be positively related to nursing job satisfaction, in that a demonstration of transformational leadership style by nurse managers or leaders resulted in increased nursing job 
satisfaction. S7 noted that transformational leadership style was associated with a moderate level of intrinsic job satisfaction but low extrinsic job satisfaction. Other leadership styles were also found to be related to nursing job satisfaction with transactional leadership having a positive correlation in S1, S3, S4 and S7 but negative in S2. S1 also found a negative correlation between passive-avoidant style and job satisfaction.

The associations between transformational leadership style and increased job satisfaction were evident in all types of hospital environments, but S1 and S6 found it to be more demonstrated in government hospitals than private hospitals resulting in higher job satisfaction. However, the more satisfaction level in government hospitals compared to private ones could be explained by other factors such as low supervision levels in these settings.

Transformational leadership was also associated with other outcomes including leader's satisfaction, extra effort and leadership effectiveness. In S3, they were more positively related to transformational leadership than transactional style. Other observed influences of transformational leadership through job satisfaction included the intention to stay at current work in S2 and organisational commitment and general health status in S6.

Job satisfaction was a moderate level in S2, S3, and S8 and moderate with intrinsic but low with extrinsic job satisfaction in S7. Nurses in public hospital had a higher level of job satisfaction than those in private sector as noted in S1. However, S6 did not find any significant difference in all hospital types.

\subsection{Themes}

The appraisal identified the three main themes presented below.

\subsubsection{How Transformational Leadership Style Improves Nursing Job Satisfaction}

Transformational leadership was found to increase job satisfaction of staff nurses through its dimensions. S1 - S3 and S7 directly examined the relationship between transformational leadership dimensions and nurse job satisfaction, and S1 and S7 found that the greatest job satisfaction was due to leaders' demonstration of inspirational motivation. S8 similarly focused on them as challenging the process, inspiring a shared vision, enabling others to act, modelling the way and encouraging the heart. Even though the relationship of other attributes was not reported, it was possible they impacted on job satisfaction. Transactional leadership style was also found to improve job satisfaction through its attributes, particularly contingent reward that lead to the greatest extrinsic job satisfaction in S1 and S7.

4.2.2 Nurse Empowerment and Workplace Support Mediated the Relationship Between Transformational Leadership and Job Satisfaction

Transformational leadership also had an impact on job satisfaction through indirect or mediating effects, such as workplace support and empowerment in S5 and S6. S5 suggested that employee empowerment that results from transformational leadership is critical in enhancing job satisfaction. Similarly, workplace support and the environment resulting from increased supervisor support due to transformational leadership were found to mediate the relationship between transformational leadership style and job satisfaction in S6. Job satisfaction was also shown to improve organisational commitment and general health status.

\subsubsection{Nurses Perceived Transformational Leadership to Be More Acceptable Compared to Other Leadership} Styles

The level of perception of transformational leadership style alone or compared to other styles, including transactional and laissez-faire was also reported in the studies. In S1 and S2, nurses perceived their nurse managers to demonstrate transformational leadership style more than transactional and passive-avoidant styles. Even though $\mathrm{S} 1$ found transactional leadership style to be more favoured over other types of leadership styles, nurses in S4 viewed their nurse managers to lack strong possession of any of the characteristics of transformational, transactional and passive-avoidant leadership styles. S8 found that the nurses' perception of the overall transformational leadership style of nurse managers and its subscales (earlier mentioned) was at a moderate level. $\mathrm{S} 2$ and S7 also found that staff nurses perceived their managers to use transformational leadership style more than transactional leadership. However, S3 found the opposite result where nurse leaders were perceived to demonstrate more transactional leadership than transformational leadership.

The findings in S1 were the same in both public and private hospitals; however, head nurses in government hospitals ranked higher in all transformational and transactional leadership subscales than their counterparts in private hospitals who ranked higher in passive-avoidant leadership style. On the other hand, S6 found no significant differences in the perception of transformational leadership in public, private or religious settings.

It is important to note that these findings are just perceptions which are subjective. Therefore, they may not be valid to be generalised. However, S2 and S3 may be reflective of the actual nursing practice in Saudi Arabia due to 
their contextual relevance. The wide geographical spread of these findings suggests that transformational leadership style is the most preferred and practised leadership style in different hospitals settings, including government-owned or private-owned.

\section{Discussion}

\subsection{Discussion of the Appraisal Process and Limitations}

This appraisal began with a close examination of the previous literature on leadership styles and nurse job satisfaction to identify a research problem. From the previous experience of the researcher, nurse job dissatisfaction due to poor leadership in nursing practice is a common problem yet transformational leadership style can improve job satisfaction (Atefi et al. (2014). Therefore, its impact was evaluated by critically appraising recent published quantitative nursing research.

However, the appraisal had some limitations that could affect its findings. First, it was conducted by a single researcher that increases the risk of bias. CRD (2009) noted that one researcher involved in systematic appraisals might affect quality as opposed to systematic reviews that usually include many experts in a given area undertaking the review jointly and independently. Nevertheless, the researcher consulted with the supervisors about the appropriateness and quality of the selected studies to ensure credibility.

\subsection{Discussions of the Findings}

\subsubsection{Relationship Between Transformational Leadership Style and Nursing Job Satisfaction}

Transformational leadership was found to be related to job satisfaction of hospital staff nurses in a positive manner with transformational leadership affecting overall, intrinsic or extrinsic job satisfaction. For instance, it resulted in moderate and low levels of intrinsic and extrinsic job satisfaction respectively in S7. Morsiani et al. (2017) similarly found that the dimensions of transformational leadership were positively correlated with staff nurses' job satisfaction. Consistent with these findings, a positive relationship was established between transformational leadership and job satisfaction among the employees of two Turkish hospitals in Top et al. (2013) study. However, it involved all hospital employees, and it had a low response rate (38.14\%) that could affect its generalisability and specific application into the nursing profession. Even though these findings suggest transformational leadership is directly related to job satisfaction, Brewer et al. (2016) found it not to be the case. The authors noted that transformational leadership was positively and directly correlated with other factors, including autonomy, organisational commitment, mentor support, and promotional opportunities, but indirectly related to job satisfaction.

The dimension of transformational leadership associated with the strongest relationship with job satisfaction appears not to be clearly understood with S7 citing inspirational motivation as the strongest predictor, but other studies indicating differing results. According to Mohammad et al. (2011), all the transformational leadership dimensions were correlated with job satisfaction of Jordanian private hospital nurses; however, the strongest correlation with job satisfaction (intrinsic and extrinsic) was found with intellectual stimulation. On the other hand, Morsiani et al. (2017) found idealised influence (attributed) to have the highest positive correlation. These findings are conflicting, but all the dimensions seem to increase nurses' job satisfaction with Mohammad et al. (2011) noting that they influence intrinsic job satisfaction more than extrinsic job satisfaction. Similar to the findings of S7, transformational leadership can, therefore, be used to promote satisfiers or motivators of job satisfaction postulated by Herzberg et al. (2008).

A relationship with nurse job satisfaction has also been found with other leadership styles. Transactional leadership was found to be positively correlated with job satisfaction in S1, S3, S4, and S7 but not in S2. Similarly, Morsiani et al. (2017) found positive associations with contingent reward and Management by Exception Active attributes of transactional leadership but negative with Management by Exception Passive. On the other hand, passive-avoidant leadership style was negatively associated with nurse job satisfaction as demonstrated by S1, S4 and S7 and corroborated by Morsiani et al. (2017) study. As noted in S4, it is apparent that nurse managers' leadership style has a significant influence on job satisfaction of their staff nurses with transformational style being beneficial while passive-avoidant leadership is detrimental. For transactional leadership, its usefulness and effectiveness appear to depend on its dimension employed such as contingent rewards.

Transformational leadership is also positively related to leader's satisfaction, extra effort and leadership effectiveness more than transactional as demonstrated in S3. Similarly, transformational leadership practice has been found to result in an increased effort, effectiveness of nurse managers and satisfaction with leadership (Casida and Parker, 2011; Aboshaiqah et al., 2014). In contrast, passive-avoidant style negatively affects these outcomes (Aboshaiqah et al., 2014). 
Moreover, S6 transformational leadership style correlated positively and significantly with organisation commitment. Similarly, Brewer et al. (2016) found transformational leadership to result in an increased organisational commitment that leads to more nurse satisfaction and intention to stay. Surprisingly, the relationship was stronger with organisational commitment and trust compared to job satisfaction in Top et al. (2013) study. On the other hand, transactional and passive-avoidant leadership styles have been found to be negatively correlated with staff's affective commitment to their hospitals (Kodama et al., 2016). Therefore, transformational leadership appears to be more effective in increasing nurse job satisfaction, organisational commitment, and retention compared to transactional and passive-avoidant leadership approaches.

The finding that transformational leadership style led to job satisfaction in all the included studies despite being conducted in different cultural contexts was surprising. According to Hofstede's (2001) theory of cultural differences, subjects with different value systems are expected to interpret and respond to surveys differently. Leadership styles also tend to be culturally linked or biased; hence, can be influenced by cultural differences (Jogulu, 2010). These variations in culture were expected to affect the definition and perception of transformational leadership style in different contexts and affect the relationships in different studies. However, it appears that the leadership style was appropriately applied based on the cultural interpretation and cognisance of workforce diversity as noted by Jogulu (2010) that resulted in its effectiveness in all settings.

\subsection{Discussion of the Themes}

\subsubsection{How Transformational Leadership Style Improves Nursing Job Satisfaction}

The dimensions of transformational leadership that were evaluated in S1 - S3 and S7 - S8 could be responsible for the increased nurse job satisfaction. Improvement of nurse job satisfaction by transformational leadership could be attributed to Bass's (1985) explanation that transformational leaders tend to encourage critical thinking and creativity among their followers that act as motivators to get more involved in work resulting in a greater degree of satisfaction with work and organisational commitment.

The strongest relationship between inspirational motivation and job satisfaction was found in S1 and S7. As noted in S1, leaders who demonstrate this characteristic develop vision and values team spirit as well as individual autonomy that promote job satisfaction. S8 also noted that inspiring a shared vision influences job satisfaction of staff nurses by giving a clear vision and mission of the organisation as well as showing interest in the vision. Nurses will, therefore, easily understand the goals of their organisations making it easier for them to implement the required processes. This is consistent with Avolio's (2011) arguments that inspirational motivation is associated with a clear articulation of vision, support for goal achievement and responses and simplification of complex issues. Moreover, inspirational leaders encourage their followers to observe moral values in their work that comes with increased responsibility and subsequent satisfaction as postulated by Herzberg's theory (Herzberg, 1974; Bass and Rigio, 2006).

On the other hand, idealised influence instils pride and faith to overcome challenges and question status quo; thus, enabling nurses to face their work with courage and confidence resulting in job satisfaction (Bass and Rigio, 2006). It was, therefore, surprising that $\mathrm{S} 3$ found a negative, though an insignificant relationship between this attribute and job satisfaction. A probable explanation for this relationship is that a demonstration of too much charisma could derail rather than increase the confidence of the followers to make well-informed decisions and take action.

S1, S3 and S7 demonstrated a positive effect for individual consideration and profession support on job satisfaction. Schwartz et al. (2011) similarly observed that individualised consideration was key to responding to the needs of the staff nurses, appreciating their contributions, and creating a supportive environment for growth and self-fulfilment. Praise and recognition are facets of individualised consideration and intrinsic factors of job satisfaction that can improve job satisfaction (Herzberg et al., 2008). As noted by Baggett et al. (2016), recognition and support among other outcomes such as safety, trust, respect, teamwork, collaboration, and autonomy are caring behaviours that result from nurses feeling cared for. Athey et al. (2016) also found work autonomy to be a strong predictor of job satisfaction as increased autonomy allows nurse practitioners to fully utilise their skills and explore full potential that comes with satisfaction.

For intellectual stimulation, leaders who demonstrate this attribute encourage creativity among their followers and involve them in critical decision-making and problem-solving processes (Avolio et al., 1999; Bass and Riggio, 2006). Similarly, the satisfaction of staff nurses with their job could be attributed to the feeling of participation in making not only patient-related decisions but also contributing to the running of the organisation. Masood and Afsar (2017) also noted that intellectual stimulation could also result in innovation through psychological empowerment, intrinsic motivation and knowledge sharing. As a result, S3 finding that intellectual motivation was 
negatively related to job satisfaction could be due to uncertainties and doubts from facts that should otherwise promote creativity and reasoning.

In overall, transformational attributes are in line with McGregor's (1960) Theory Y Philosophy of Management. In this theory, Douglas McGregor proposed that leaders who hold Theory Y beliefs allow their followers to work without constant supervision as they see their work as motivating and rewarding. Moreover, these leaders involve their followers in decision-making processes. As a result, the employees become committed in their work and tend to be self-directed and creative in achieving organisational goals. Therefore, the major function of Theory $\mathrm{Y}$ leaders is to provide support including favourable work environment by removing obstacles, providing guidance and encouraging growth to their subordinates. This is further supported by the findings of Pastor and Mayo (2006) that transformational leadership was positively associated with stronger beliefs of Theory Y. Hence, these attributes will improve intrinsic and extrinsic factors affecting for job satisfaction.

Transactional leadership style similarly improved job satisfaction through its attributes. In S7, contingent reward had the greatest extrinsic satisfaction. Gitinane (2013) noted that transactional leaders usually use it in exchange for performance. It seems that it is the expected benefits of transactional leadership style that leads to job satisfaction. In overall, transactional leadership could be as effective as transformational style, but the best outcomes could be realised when both styles are combined (Casida and Parker, 2011; Aboshaiqah et al., 2014).

5.3.2 Empowerment and Workplace Support Mediated the Relationship Between Transformational Leadership and Nurses' Job Satisfaction

S5 and S6 identified empowerment and workplace support to play mediating role in transformational leadership and nurse job satisfaction relationships. The empowered staff nurses are motivated to accomplish tasks and goals resulting in job satisfaction similarly to the systematic review findings by Cicolini et al. (2015) that showed positive relationship between empowerment and nurses' job satisfaction. The authors noted that there are two types of empowerment - structural and psychological - that affect job satisfaction differently with structural empowerment leading to psychological empowerment that in turn leads to job satisfaction. On the other hand, Attari (2013) noted that transformational leadership affects nurse psychological empowerment and its dimensions related to the meaning of the work, competence required to do the job, autonomy and control over the work. This psychological empowerment has been found to independently lead to job satisfaction (Ouyang et al., 2015). Therefore, it can mediate the impact of transformational leadership on nursing job satisfaction or enhance job satisfaction independently as noted in S5.

Despite these findings, nurse empowerment can also be affected by a range of factors, such as education and training. Rashed and eldeen Fekry (2015) found a positive relationship between empowerment and high level of education and staff experience. As a result, providing the nurses with empowering opportunities like advanced education and training can significantly improve their job satisfaction level. However, empowerment might not be productive as envisioned by theorist Rosabeth Kanter who stated that staff empowerment with resources and training is required for efficient performance (Kanter, 1979). On the contrary, empowered staff nurses may abuse their elevated status due to increased authority and autonomy leading to a power struggle with the management.

Workplace support and professional support are also positively correlated with job satisfaction as demonstrated in S6. As noted by (Higgins, 2015), supportive practice environments due to transformational leadership can improve job satisfaction of nurses and result in better patient outcomes. Nevertheless, the support observed in S6 could be attributed to the stressful hospital environment in which the study was conducted that makes staff nurses to prefer supportive leaders leading to job satisfaction. The path gaol theory of leader effectiveness developed by Robert House in 1971 postulated that a leader's role is to clarify the path towards the goal, eliminate roadblocks and increase rewards along the way (House, 1971). Supportive leaders also strive to create friendly environment and increase surbodinates' self-esteem; hence the most preferred in stressful, boring and hazardous work settings like hospital nursing units (House, 1971).

\subsubsection{Nurses Perceived Transformational Leadership to be More Acceptable Compared to Other Leadership Styles}

S1 found that nurses perceived their nurse managers to demonstrate transformational leadership style more than other styles, including transactional and passive-avoidant. S2 also found that staff nurses viewed their managers to practice transformational rather than transactional leadership. It appears nursing staff perceives their leaders to use transformational leadership style, to a greater extent as observed by Andrews et al. (2012) and Aboshaiqah et al. (2014). Compared to other forms, transformational leadership was perceived to be more acceptable due to its positive correlation with job satisfaction. The contrasting finding of S4 that staff nurses did not perceive their nurse managers to possess any of the leadership styles is surprising considering there is leadership at every institution. 
Nevertheless, Avolio et al. (1999) noted that leaders tend to demonstrate more than one leadership style. Consistent with this argument, Casida and Parker (2011) found contingent rewards of transactional leadership to be frequently used with transformational leadership to improve nurse and organisational outcomes.

One particular challenge with these findings is that they were perceptions that can be influenced by several factors. For instance, S1 found that government hospital nurses reported higher transformational leadership than their private counterparts. This could be attributed to setting differences that dictate management policies and conditions of work and engagement between nurse managers and staff nurses. It appears that working unit also influences the type of leadership style with S3 finding that head nurses in critical care units used transactional leadership more than transformational. Aboshaiqah et al. (2014) similarly found that transactional leadership style is more likely to be used by nurse supervisors in critical and special care units as opposed to transformation style frequently used in general care units. The possible explanation for this is that transactional trait could be effective in addressing the complex needs of patients in critical care areas with a high tendency of errors.

Of great influence are the demographic variables such as working years found in S4 to correlate with transformational and transactional leadership styles. For instance, Alghamdi et al. (2017) found the perception of nurse managers' leadership style to vary with their gender whereby male managers were perceived to demonstrate higher transformational leadership attributes than female managers. However, the authors the instruments of measuring perceived transformational leadership behaviours of the nurse managers may not accurately and reliably used in Saudi Arabia as they were developed based on samples of the United States nurses with different gender roles compared to Saudi nurses. Contrarily, Eneh et al. (2012) did not find any influence of background or demographic variables of staff nurses on their perceptions of nursing leadership practices complicating the interpretations of these relationships.

\subsubsection{Problematic Nature of 'Evidence' and its Collection, Collation, and Interpretation}

The presented evidence is associated with challenges related to the contextual application as well as the methods that were used to collect, collate and interpret it. Apart from S1, the rest of the studies were based on a theoretical framework of full range leadership theory that may be affected by the study setting and different interpretation of leadership style. The use of questionnaires to collect data on specific outcomes limits the freedom of the participants to give adequate information regarding the topic under investigation. This affects the reliability of the collected data. Moreover, the use of English language in non-English settings may hinder the participation of choosing leaders, and the varying analytical variables for analysis in different studies affect the analytical approach in individual studies and their outcomes.

\subsection{Identification of Gaps in the Evidence}

There are pertinent issues related to the evidence presented in this critical appraisal. Most of the studies were conducted in different cultural contexts that may not be applicable to the Saudi hospitals. The perceptions and interpretations of leadership styles also vary with individuals as well as culture, making it difficult to obtain conclusive results. For instance, S2 focused on Saudi nurses only to make its conclusions yet expatriates might have different perceptions and it is conducted in public hospitals only yet private and military hospitals could have different administration experiences. Even though majority the of the nurses perceived their leaders to use transformational style, Eneh et al. (2012) noted that perceptions are personal opinions that are subjective and difficult to measure. The participation of nursing leaders is also necessary to help in formulating a favourable work environment that allows full utilisation of potential and improving nursing care. The evidence could also be affected by the bias of the included studies as they mainly involved cross-sectional designs that do not show cause and effect relationships

\subsection{Implications for Practice, Management, Education, and Future Research}

Practice: All the studies acknowledge that nursing leadership styles are related to job satisfaction and nursing retention with transformational leadership being the most effective style. It results in several benefits such as intention to stay, improved organisational commitment, and general health status that lead to better nurse and patient outcomes. These findings imply that nurses' job satisfaction that is can be improved by transformational leadership is critical for better outcomes. As a result, nurse leaders should develop systems to monitor, assess, address, and evaluate the specifics of the nurses' work and their work environment and collaborate with them in a mutually-supportive and transparent manner to sustain subordinate job satisfaction.

Health management: The hospital management or administrators should focus on effective support and training programmes and life coaching methods such as Belbin role assessment, individual coaching, group session and working with other nursing degrees to provide their nurse managers with effective leadership skills such as 
transformational leadership (Williamson, 2008).

Moreover, this appraisal is critical to the implementation of Saudisation policy whereby effective nursing leadership, such as transformational leadership could be used by Saudi hospital managers or administrators as a potent intervention for enhancing nursing job satisfaction. However, a lot of caution is required when replacing the experienced non-Saudi nurse managers who mainly practice transformational leadership style with the less experienced Saudi predominantly using passive laissez-faire leadership style (Alshammari, 2014).

Emphasis should also be placed on innovation to facilitate engagement between nurse managers and staff nurses and increase effective supervision to achieve the organisational goals and improve nurse job satisfaction. A clear hospital vision and mission and nurse empowerment will not only increase job satisfaction among nurses but also leads to role model nurse managers who inspire and instil trust and confidence in their followers to transform and become transformational leaders.

Education: Transformational leadership concepts can be included in the in-service education programmes and leadership training for nurse managers conducted within or outside academic settings (Casida \& Parker, 2011).

Future research: Due to the dearth of information on the cultural influence on transformational leadership style and job satisfaction, future studies should investigate the effects of cultural beliefs and practices in leadership styles and nursing job satisfaction as well as other factors that contribute to transformational leadership in the hospital organisations. This would help to identify the potential barriers to developing transformational nurse leaders or managers. It is also clearly evident that most of the previous research has targeted staff nurses while evaluating job satisfaction associated with transformational leadership style, leaving out nurse managers, nurse administrators and nurse educators who play a significant role in nursing education and practice. Future research should, therefore, include this target population to allow comparison from the leader-follower perspective.

\section{Competing Interests Statement}

The authors declare that there are no competing or potential conflicts of interest.

\section{References}

Abdelhafiz, I. M., Alloubani, A. M. D., \& Almatari, M. (2016). Impact of leadership styles adopted by head nurses on job satisfaction: a comparative study between governmental and private hospitals in Jordan. Journal of Nursing Management, 24(3), 384-392. https://doi.org/10.1111/jonm.12333

Aboshaiqah, A. (2016). Strategies to address the nursing shortage in Saudi Arabia. International Nursing Review, 63(3), 499-506. https://doi.org/10.1111/inr.12271

Aboshaiqah, A. E., Hamdan-Mansour, A. M., Sherrod, D. R., Alkhaibary, A., \& Alkhaibary, S. (2014). Nurses' perception of managers' leadership styles and its associated outcomes. American Journal of Nursing Research, 2(4), 57-62.

Abou Hashish, E. (2016). Relationship between ethical work climate and nurses' perception of organizational support, commitment, job satisfaction and turnover intent. Nursing Ethics, 24(2), 151-166. https://doi.org/10.1177/0969733015594667

Abualrub, R. F., \& Alghamdi, M. G. (2012). The impact of leadership styles on nurses' satisfaction and intention to stay among Saudi nurses. Journal of Nursing Management, 20(5), 668-678. https://doi.org/10.1111/j.1365-2834.2011.01320.x

Abu-Zinadah, S. (2004). The situation of Saudi nursing. Health Forum, 52, $42-43$.

Akobeng, A. K. (2005). Principles of evidence based medicine. Archives of Disease in Childhood, 90(8), 837-840. https://doi.org/10.1136/adc.2005.071761

Alshahrani, F. M. M., \& Baig, L. A. (2016). Effect of leadership styles on job satisfaction among critical care nurses in Aseer, Saudi Arabia. Journal of the College of Physicians and Surgeons Pakistan, 26(5), 366-370.

Alshammari, F. (2014). Nursing leadership in the Ministry of Health hospitals of Saudi Arabia (Doctoral dissertation, Royal Melbourne Institute of Technology University, Melbourne, Australia).

Andrews, D. R., Richard, D. C., Robinson, P., Celano, P., \& Hallaron, J. (2012). The influence of staff nurse perception of leadership style on satisfaction with leadership: A cross-sectional survey of pediatric nurses. International Journal of Nursing Studies, 49(9), 1103-1111. https://doi.org/10.1016/j.ijnurstu.2012.03.007

Asegid, A., Belachew, T., \& Yimam, E. (2014). Factors influencing job satisfaction and anticipated turnover among nurses in Sidama zone public health facilities, South Ethiopia. Nursing Research and Practice, 2014. 
https://doi.org/10.1155/2014/909768

Atefi, N., Abdullah, K. L., Wong, L. P., \& Mazlom, R. (2014). Factors influencing registered nurses' perception of their overall job satisfaction: a qualitative study. International Nursing Review, 61(3), 352-360. https://doi.org/10.1111/inr.12112

Atefi, N., Lim Abdullah, K., Wong, L. P., \& Mazlom, R. (2015). Factors influencing job satisfaction among registered nurses: A questionnaire survey in Mashhad, Iran. Journal of Nursing Management, 23(4), 448-458. https://doi.org/10.1111/jonm.12151

Athey, E. K., Leslie, M. S., Briggs, L.A., Park, J., Falk, N. L., Pericak, A., El-Banna, M. M., \& Greene, J. (2016). How important are autonomy and work setting to nurse practitioners' job satisfaction?. Journal of the American Association of Nurse Practitioners, 28(6), 320-326. https://doi.org/10.1002/2327-6924.12292

Attari, M. (2013). The Impact of Transformational Leadership on Nurse Psychological Empowerment. International Journal of Hospital Research, 2(2), 71-76.

Avolio, B. (2011). Full range leadership development (2nd ed.) Los Angeles: SAGE. https://doi.org/10.4135/9781483349107

Avolio, B. J., \& Bass, B. M. (2004). Multifactor Leadership Questionnaire. Manual and Sampler Set. (3rd ed.). Redwood City, CA: Mindgarden.

Avolio, B., Bass, B., \& Jung, D. (1999). Re-examining the components of transformational and transactional leadership using the Multifactor Leadership. Journal of Occupational and Organizational Psychology, 72(4), 441-462. https://doi.org/10.1348/096317999166789

Baggett, M., Giambattista, L., Lobbestael, L., Pfeiffer, J., Madani, C., Modir, R., ... \& Davidson, J. E. (2016). Exploring the human emotion of feeling cared for in the workplace. Journal of Nursing Management, 24(6), 816-824. https://doi.org/10.1111/jonm.12388

Barker, J. (2013). Evidence-Based Practice for Nurses. London: SAGE Publications.

Barlow, K. M. (2013). A meta-analysis of transformational leadership and subordinate nursing personnel organizational commitment, job satisfaction, and turnover intentions (Doctoral dissertation, University of Maryland, Baltimore).

Bass B. M. (1985). Leadership performance beyond expectations. New York: Academic Press.

Bass, B., \& Avolio, B. (1994). Improving organizational effectiveness through transformational leadership. Thousand Oaks, Calif: Sage.

Bass, B. M., \& Bass, R. (2008). The Bass handbook of leadership: Theory, research, and managerial applications. New York: Free, Print 89.

Bass, B., \& Riggio, R. (2006). Transformational leadership (2nd ed.). New York: Routledge.

Belbin. (2009). The Belbin guide to succeeding at work. London: A. \& C. Black.

Bettany-Saltikov, J., \& McSherry, R. (2016). How to do a systematic literature review in nursing: a step-by-step guide (2nd ed.). McGraw-Hill Education (UK).

Boaz, A., Baeza, J., \& Fraser, A. (2011). Effective implementation of research into practice: an overview of systematic reviews of the health literature. BMC Research Notes, 4(1), 212. https://doi.org/10.1186/1756-0500-4-212

Bormann, L., \& Abrahamson, K. (2014). Do staff nurse perceptions of nurse leadership behaviors influence staff nurse job satisfaction? The case of a hospital applying for Magnet ${ }^{\circledR}$ designation. JONA: The Journal of Nursing Administration, 44(4), 219-225. https://doi.org/10.1097/NNA.0000000000000053

Braun, S., Peus, C., Weisweiler, S., \& Frey, D. (2013). Transformational leadership, job satisfaction, and team performance: A multilevel mediation model of trust. The Leadership Quarterly, 24(1), pp.270-283. https://doi.org/10.1016/j.leaqua.2012.11.006

Brewer, C. S., Kovner, C. T., Djukic, M., Fatehi, F., Greene, W., Chacko, T. P., \& Yang, Y. (2016). Impact of transformational leadership on nurse work outcomes. Journal of Advanced Nursing, 72(11), 2879-2893. https://doi.org/10.1111/jan.13055

Castle, J. E. (2003). Maximizing research opportunities: Secondary data analysis. Journal of Neuroscience Nursing, 35(5), 287. https://doi.org/10.1097/01376517-200310000-00008 
Centre for Reviews and Dissemination. (2009). Systematic reviews: CRD's guidance for undertaking reviews in health care (University of York, Centre for Reviews \& Dissemination).

Chaudhry, A. Q., \& Javed, H. (2012). Impact of transactional and laissez faire leadership style on motivation. International Journal of Business and Social Science, 3(7).

Cheng, H. G., \& Phillips, M. R. (2014). Secondary analysis of existing data: Opportunities and implementation. Shanghai Archives of Psychiatry, 26(6), 371.

Choi, S., Goh, C., Adam, M., \& Tan, O. (2016). Transformational leadership, empowerment, and job satisfaction: the mediating role of employee empowerment. Human Resources for Health, 14(1). https://doi.org/10.1186/s12960-016-0171-2

Chou, L. P., Li, C. Y., \& Hu, S. C. (2014). Job stress and burnout in hospital employees: comparisons of different medical professions in a regional hospital in Taiwan. BMJ open, 4(2), e004185. https://doi.org/10.1136/bmjopen-2013-004185

Cicolini, G., Comparcini, D., \& Simonetti, V. (2014). Workplace empowerment and nurses' job satisfaction: A systematic literature review. Journal of Nursing Management, 22(7), 855-871. https://doi.org/10.1111/jonm. 12028

Cohen, L., Manion, L., \& Morrison, K. (2013). Research methods in education. Routledge. https://doi.org/10.4324/9780203720967

Coughlan, M., Cronin, P., \& Ryan, F. (2013). Doing a literature review in nursing, health and social care. London: Sage.

Creswell, J. W. (2013). Research design: Qualitative, quantitative, and mixed methods approaches (4th ed.). Sage publications.

Cummings, G. G., MacGregor, T., Davey, M., Lee, H., Wong, C. A., Lo, E., ... \& Stafford, E. (2010). Leadership styles and outcome patterns for the nursing workforce and work environment: A systematic review. International Journal of Nursing Studies, 47(3), 363-385. https://doi.org/10.1016/j.ijnurstu.2009.08.006

D'Auria, J. P. (2007). Using an evidence-based approach to critical appraisal. Journal of Pediatric Health Care, 21(5), 343-346. https://doi.org/10.1016/j.pedhc.2007.06.002

Doolan, D. M., \& Froelicher, E. S. (2009). Using an existing data set to answer new research questions: a methodological review. Research and Theory for Nursing Practice, 23(3), 203. https://doi.org/10.1891/1541-6577.23.3.203

Ellis, P. (2016). Understanding research for nursing students (3rd ed.). Exeter: Learning Matters.

Ellis, J., \& Hartley, C. (2010). Managing and coordinating nursing care. Philadelphia, PA: Lippincott Williams \& Wilkins.

Greenhalgh, T., \& Peacock, R. 2005). Effectiveness and efficiency of search methods in systematic reviews of complex evidence: audit of primary sources. BMJ, 331(7524), 1064-1065. https://doi.org/10.1136/bmj.38636.593461.68

Haddad, A., \& Dagamseh, S. M. (2016). Nurses' intent to leave and job satisfaction in hematology/oncology areas: Implications for policy and practice. $J$ Nurs Care, 5, 363. https://doi.org/10.4172/2167-1168.1000363

Herzberg, F. (1974). Motivation-hygiene profiles: Pinpointing what ails the organization. Organizational Dynamics, 3(2), 18-29. https://doi.org/10.1016/0090-2616(74)90007-2

Herzberg, F., Mausner, B., \& Snyderman, B. (2008). The motivation to work. New Brunswick, N.J.: Transaction Publishers.

Higgins, E. A. (2015). The influence of nurse manager transformational leadership on nurse and patient outcomes: Mediating effects of supportive practice environments, organizational citizenship behaviours, patient safety culture and nurse job satisfaction. (Doctoral dissertation, The University of Western Ontario).

Higgins, J. P., \& Green, S. (2008). Cochrane handbook for systematic reviews of interventions. England: John Wiley \& Sons. https://doi.org/10.1002/9780470712184

Hofstede, G. (2001). Culture's consequences: Comparing values, behaviors, institutions, and organizations across nations. Thousand Oaks, CA: Sage.

House, R. J. (1971). A path goal theory of leader effectiveness. Administrative science quarterly, 321-339. 
https://doi.org/10.2307/2391905

House, R., \& Wigdor, I. (1967). Herzberg's dual-factor theory of job satisfaction and motivation: A review of the $\begin{array}{llll}\text { evidence and a } & \text { criticism. Personnel }\end{array}$ https://doi.org/10.1111/j.1744-6570.1967.tb02440.x

Ioannou, P., Katsikavali, V., Galanis, P., Velonakis, E., Papadatou, D., \& Sourtzi, P. (2015). Impact of job satisfaction on Greek nurses' health-related quality of life. Safety and Health at Work, 6(4), 324-328. https://doi.org/10.1016/j.shaw.2015.07.010

Jesson, J., Matheson, L., \& Lacey, F. (2011). Doing your literature review: traditional and systematic techniques. Sage: London.

Khan, K., Kunz, R., Kleijnen, J., \& Antes, G. (2011). Systematic reviews to support evidence-based medicine: How to review and apply findings of healthcare research (2nd ed.). London: Hodder Arnold.

Kingdom of Saudi Arabia Vision 2030. (n.d). National Transformation Program 2020. Retrieved September 13, 2017, from http://vision2030.gov.sa/en

Kitchenham, B. (2004). Procedures for performing systematic reviews. Keele, UK, Keele University, 33(2004), $1-26$.

Kodama, Y., Fukahori, H., Sato, K., \& Nishida, T. (2016). Is nurse managers' leadership style related to Japanese staff nurses' affective commitment to their hospital?. Journal of nursing management, 24(7), 884-892. https://doi.org/10.1111/jonm.12392

Kouzes J. M., \& Posner, B. Z. (1995). The leadership challenge: How to keep getting extraordinary things done in organization. Jossey-Bass, San Francisco.

Kruse, K. (2013). What is leadership? Forbes Magazine, 1-3.

Kvist, T., Voutilainen, A., Mäntynen, R., \& Vehviläinen-Julkunen, K. (2014). The relationship between patients' perceptions of care quality and three factors: nursing staff job satisfaction, organizational characteristics and patient age. BMC Health Services Research, 14(1), 466. https://doi.org/10.1186/1472-6963-14-466

Lamadah, S. M., \& Sayed, H. Y. (2014). Challenges facing nursing profession in Saudi Arabia. Journal of Biology, Agriculture and Healthcare, 4(7), 20-25.

Law, M., Stewart, D., Pollock, N., Letts, L., Bosch, J., \& Westmorland, M. (1998a). Critical Review Form-Quantitative Studies [On-Line]. Accessed 13//2017.

Law, M., Stewart, D., Pollock, N., Letts, L., Bosch, J. and Westmorland, M. (1998b). Guidelines for Critical Review Form-Quantitative Studies [On-Line]. Retreived from http://www. srs-mcmaster.caam

Lazar, A. (2010). Spirituality and job satisfaction among female Jewish Israeli hospital nurses. Journal of Advanced Nursing, 66(2), 334-344. https://doi.org/10.1111/j.1365-2648.2009.05172.x

Lin, P., MacLennan, S., Hunt, N., \& Cox, T. (2015). The influences of nursing transformational leadership style on the quality of nurses' working lives in Taiwan: A cross-sectional quantitative study. BMC Nursing, 14(1). https://doi.org/10.1186/s12912-015-0082-x

Littlejohn, L., Campbell, J., Collins-McNeil, J., \& Khayile, T. (2012). Nursing shortage: A comparative analysis. International Journal of Nursing, 1(1), 22-27.

LoBiondo-Wood, G., \& Haber, J. (1998). Nursing Research: Methods, Critical Appraisal \& Utilization (4th ed.). Mosby Inc, St. Louis, MO.

Locke, E. A. (1969). What is job satisfaction? Organizational Behavior and Human Performance, 4(4), 309-336. https://doi.org/10.1016/0030-5073(69)90013-0

McCleskey, J. A. (2014). Situational, transformational, and transactional leadership and leadership development. Journal of Business Studies Quarterly, 5(4), 117.

Melnyk, B. M., \& Fineout-Overholt, E. (2011). Evidence-based practice in nursing \& healthcare, A guide to best practice (2nd ed.). Philadelphia: Lippincot Williams \& Wilkins.

Ministry of Health. (2017). Statistical Yearbook. Retrieved September 13, 2017, from http://www.moh.gov.sa/en/ministry/statistics/book/pages/default.aspx

Mohammad, S. I. S., Al-Zeaud, H. A., \& Batayneh, A. M. E. B. (2011). The relationship between transformational leadership and employees' satisfaction at Jordanian private hospitals. Business and Economic Horizons, 5(2), 
35-46. https://doi.org/10.15208/beh.2011.13

Morsiani, G., Bagnasco, A., \& Sasso, L. (2017). How staff nurses perceive the impact of nurse managers' leadership style in terms of job satisfaction: a mixed method study. Journal of Nursing Management, 25(2), 119-128. https://doi.org/10.1111/jonm.12448

Moule, P., \& Goodman, M. (2009). Nursing Research: An introduction. London: Sage Publication.

Mufti, M. H. (2000). Healthcare development strategies in the Kingdom of Saudi Arabia. New York: Kluwer Academic/Plenum Publishers.

Murray, A. (2010). The Wall Street journal essential guide to management: lasting lessons from the best leadership minds of our time. Harper Business.

Nantsupawat, A., Kunaviktikul, W., Nantsupawat, R., Wichaikhum, O. A., Thienthong, H., \& Poghosyan, L. (2017). Effects of nurse work environment on job dissatisfaction, burnout, intention to leave. International Nursing Review, 64(1), 91-98. https://doi.org/10.1111/inr.12342

NCBI. (2013, February 14). Use MeSH to Build a Better PubMed Query. Retrieved from https://www.youtube.com/watch?v=uyF8uQY9wys (accessed: 30/09/2017).

Nielsen, K., Randall, R., Yarker, J., \& Brenner, S. O. (2008). The effects of transformational leadership on followers' perceived work characteristics and psychological well-being: A longitudinal study. Work \& Stress, 22(1), 16-32. https://doi.org/10.1080/02678370801979430

Negussie, N., \& Demissie, A. (2017). Relationship between leadership styles of nurse managers and nurses' job satisfaction in Jimma University Specialized Hospital. Ethiopian Journal of Health Sciences, 23(1), 50-58.

Newell, R., \& Burnard, P. (2010). Research for evidence-based practice in healthcare (2nd ed.). West Sussex, UK: Wiley Blackwell.

Northouse, P. G. (2010). Leadership: Theory and practice (5th ed.). Los Angels: Sage publications.

Ouyang, Y. Q., Zhou, W. B., \& Qu, H. (2015). The impact of psychological empowerment and organisational commitment on Chinese nurses' job satisfaction. Contemporary Nurse, 50(1), 80-91. https://doi.org/10.1080/10376178.2015.1010253

Northumbria University, Faculty of Health and Life Sciences (2017). Dissertation: Systematic Appraisal of Published Nursing Research. [online] Elp.northumbria.ac.uk. Retrieved October 13, 2017, from https://elp.northumbria.ac.uk/webapps/blackboard/content/listContent.jsp?course_id=_284315_1\&content_i $\mathrm{d}=$ _4212730_1\&mode=reset

Parahoo, K. (2014). Nursing research: principles, process and issues (3rd ed.). Basingtoke: Macmillan.

Pastor, J. C., \& Mayo, M. (2006). Transformational and transactional leadership: an examination of managerial cognition among Spanish upper echelons. IE Working Paper. https://doi.org/10.2139/ssrn.1015363

Payne, G., \& Payne, J. (2004). Secondary analysis. In Key concepts in social research. London: SAGE Publications. https://doi.org/10.4135/9781849209397

PMC Help [Internet]. Bethesda (MD): National Center for Biotechnology Information (US); 2005. Retrieved March 9, 2017, from https://www.ncbi.nlm.nih.gov/books/NBK3825/\#pmchelp.Using_the_ Advanced_Search_Builde

Polit, D. F. (2013). Statistics and data analysis for nursing research. Pearson new international edition.

Rousseau, D. M. (2006). Is there such a thing as "evidence-based management"? Academy of management review, 31(2), 256-269. https://doi.org/10.5465/amr.2006.20208679

Sackett, D. L., \& Strauss, S. E. (2000). Evidence based medicine: How to practice and teach EBM (2nd ed.). Edinburgh: Churchill Livingstone.

Schwartz, D. B., Spencer, T., Wilson, B., \& Wood, K. (2011). Transformational leadership: Implications for nursing leaders in facilities seeking magnet designation. AORN Journal, 93(6), 737-748. https://doi.org/10.1016/j.aorn.2010.09.032

Shang, D. J., Friese, D. C. R., Wu, M. E., \& Aiken, L. H. (2013). Nursing practice environment and outcomes for oncology nursing. Cancer Nursing, 36(3), 206. https://doi.org/10.1097/NCC.0b013e31825e4293

Shortell, S. M. (2006). Promoting evidence-based management. Frontiers of Health Services Management, 22(3), 23. https://doi.org/10.1097/01974520-200601000-00003 
Silverman, D. (2011). Interpreting qualitative data: A guide to the principles of qualitative research. SAGE Publications Limited.

Sohrabi, Z., \& Zarghi, N. (2015). Evidence-based management: An Overview. Creative Education, 6(16), 1776. https://doi.org/10.4236/ce.2015.616180

Sojane, J. S., Klopper, H. C., \& Coetzee, S. K. (2016). Leadership, job satisfaction and intention to leave among registered nurses in the North West and Free State provinces of South Africa. Curationis, 39(1), 1-10. https://doi.org/10.4102/curationis.v39i1.1585

Spector, P. (1997). Job satisfaction. Thousand Oaks [u.a.]: Sage Publ.

Sullivan, E. J., \& Garland, G. (2010). Practical leadership and management in nursing. Pearson Education.

Sveinsdóttir, H., Ragnarsdóttir, E. D., \& Blöndal, K. (2016). Praise matters: the influence of nurse unit managers' praise on nurses' practice, work environment and job satisfaction: a questionnaire study. Journal of Advanced Nursing, 72(3), 558-568. https://doi.org/10.1111/jan.12849

Top, M., Tarcan, M., Tekingündüz, S., \& Hikmet, N. (2013). An analysis of relationships among transformational leadership, job satisfaction, organizational commitment and organizational trust in two Turkish hospitals. The International Journal of Health Planning and Management, 28(3). https://doi.org/10.1002/hpm.2154

Tumulty, G. (2001). Professional development of nursing in Saudi Arabia. Journal of Nursing Scholarship, 33(3), 285-290. https://doi.org/10.1111/j.1547-5069.2001.00285.x

Whatishumanresource.com. (n.d.). Herzberg two factor theory - Human Resource l Concepts l Topics l Definitions $l$ Labour Laws. Retrieved October 13, 2017, from http://www.whatishumanresource.com/herzberg-two-factor-theory

Wiley Online Library. (n.d.). Search tips: Advanced search. Retrieved September 30, 2017, from http://onlinelibrary.wiley.com/searchTips 


\section{Appendix}

\section{Tabular Presentation of the Study Findings}

Table 1. Study 1 (S1)

\begin{tabular}{|c|c|c|c|c|c|c|c|}
\hline Author, date & \multicolumn{7}{|l|}{ Abdelhafiz et al. (2015) } \\
\hline $\begin{array}{l}\text { Study and } \\
\text { Study aim }\end{array}$ & \multicolumn{7}{|c|}{$\begin{array}{l}\text { Context/Location: Government and private hospitals in Jordan. } \\
\text { Study Design: Quantitative, cross-sectional, comparative and correlational. } \\
\text { Study Aim: To compare the leadership styles of private and public nurse managers as rated by staff nurses } \\
\text { and to interpret findings from the perspective of job satisfaction. } \\
\text { Theoretical framework: Was not clearly presented in the study. }\end{array}$} \\
\hline Sampling & \multicolumn{7}{|c|}{$\begin{array}{l}\text { Age Range and Gender: The majority of staff nurses were } 30 \text { years and below (43\%) while nurse managers } \\
\text { were over } 40 \text { years ( } 72.5 \%) \text {. Female were the majority accounting for } 67.5 \% \text {. } \\
\text { Sampling method: Multistage involving cluster sampling followed by convenience selection. } \\
\text { Inclusion criteria for sample assessed by nurse managers and assistants. } \\
\text { Inclusion criteria: For nurses: Working in the selected hospitals, hold bachelor or master degree. } \\
\text { For nurse managers: One years' experience as manger with } 24 \text { hrs accountability and responsibility for } \\
\text { operational process to research participants. } \\
\text { Sample size: Sample size calculated. } 225 \text { nurse managers and staff nurses. } 200 \text { ( } 40 \text { nurse managers and } 160 \\
\text { staff nurses returned the questionnaires }(88.8 \%) \text {. } \\
\text { Ethical issues: Ethical approval and informed consent obtained. }\end{array}$} \\
\hline Variables & \multicolumn{7}{|c|}{$\begin{array}{l}\text { Independent variables: Demographics, Hospital sector and Transformational, transactional, and } \\
\text { laissez-faire/passive-avoidant leadership styles. } \\
\text { Dependent variables: Job satisfaction level }\end{array}$} \\
\hline $\begin{array}{l}\text { Outcome } \\
\text { measures }\end{array}$ & \multicolumn{7}{|c|}{$\begin{array}{l}\text { Data Collection: Questionnaires consisting of demographic information sheet, Multi-Factor Leadership } \\
\text { Questionnaire (MLQ) 5X, and job satisfaction questionnaire and were completed by the nurse managers and } \\
\text { staff nurses. Questionnaire distributed to nurses in different shifts and collected by distributed secure boxes in } \\
\text { hospitals. } \\
\text { Validity : Content validity: Used previous authors' MLQ. } \\
\text { Reliability: The previous authors reported MLQ to have Cronbach's } \alpha \text { of above } .80 \text { for all scales. } \\
\text { Job satisfaction questionnaire was developed by the study authors and had Cronbach's } \alpha \text { of } 0.871 \text { and } 0.819 \\
\text { for public and private hospitals respectively. }\end{array}$} \\
\hline $\begin{array}{l}\text { Analysis } \\
\text { approach }\end{array}$ & \multicolumn{7}{|c|}{$\begin{array}{l}\text { Descriptive statistics, } t \text {-test, Anova, pearson's correlation, mean (M) and standardized deviation (SD) } \\
\text { Not reported for programme used }\end{array}$} \\
\hline Result & \multicolumn{7}{|c|}{ Perceived leadership styles in public and private hospital respectively: } \\
\hline & \multirow[t]{2}{*}{ Leadership styles } & \multicolumn{3}{|c|}{$\operatorname{MEAN}(\mathrm{M})=(0-4)$} & \multicolumn{2}{|c|}{$\begin{array}{l}\text { STANDARD SEVIATION } \\
(\mathrm{SD})\end{array}$} & \multirow[t]{2}{*}{ P VALUE } \\
\hline & & $P U B L$ & & PRIVATE & PUBLIC & PRIVATE & \\
\hline & TRANSFORMATIONAL & 2.96 & & 2.48 & .72 & .71 & $P<.001$ \\
\hline & TRANSACTIONAL & 2.87 & & 2.39 & .70 & .67 & $P<.001$ \\
\hline & PASSIVE AVOIDENT & .92 & & 1.36 & .95 & .90 & P.01 \\
\hline & \multicolumn{7}{|c|}{ Relationship between leadership styles and job satisfaction: } \\
\hline & \multicolumn{2}{|l|}{ LEADERSHIP STYLES } & \multicolumn{3}{|c|}{ CORRELATION } & \multicolumn{2}{|l|}{ P VALUE } \\
\hline & \multicolumn{2}{|l|}{ TRANSFORMATIONAL } & \multicolumn{3}{|c|}{$\mathrm{r}=.374$} & \multicolumn{2}{|l|}{$\mathrm{p}<0.001$} \\
\hline & \multicolumn{2}{|l|}{ TRANSACTIONAL } & \multicolumn{3}{|c|}{$\mathrm{r}=.391$} & \multicolumn{2}{|l|}{$\mathrm{p}<0.001$} \\
\hline
\end{tabular}




\begin{tabular}{|l|l|l|l|}
\hline Comments & PASSIVE AVOIDENT & $\mathrm{r}=-.24$ & $\mathrm{p}<0.001$ \\
\hline & $\begin{array}{l}\text { This study demonstrates that hospital setting (public or private) plays a role in nursing perception of } \\
\text { leadership styles. The use of different settings also tends to limit the potential bias related to research setting; } \\
\text { thus, it is crucial for use in this study. Moreover, the authors did not measure factors affecting job satisfaction } \\
\text { but measured emotional state for staff nurse. Nursing staff in public sector had higher level of job satisfaction } \\
\text { than their private counterparts }[\mathrm{M}=5.40 \text { and } \mathrm{SD}=1.01 ; \mathrm{M}=4.85, \mathrm{SD}=0.94 ; \mathrm{T}=4.18, \mathrm{P}<0.001 \text { respectively). } \\
\text { All dimensions for leadership styles associated with job satisfaction except passive } \\
\text { management-by-exception and laissez faire }(\mathrm{r}=-240 \text { and } \mathrm{r}=-.225 ; \mathrm{p}<.001 \text { respectively). }\end{array}$ \\
\hline
\end{tabular}

Table 2. Study 2 (S2)

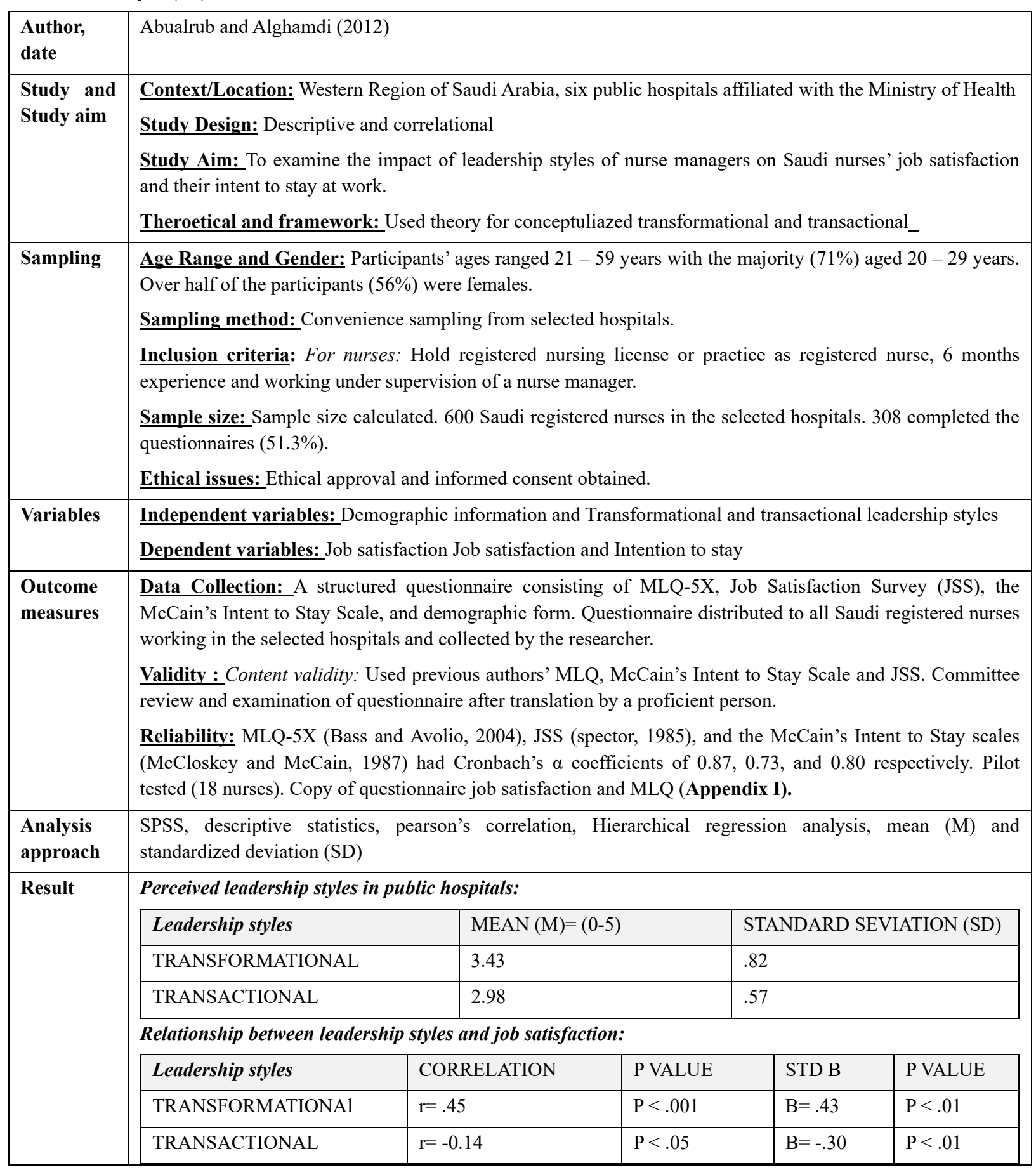


Comments $\quad$ The study evaluation of the impact of transformational leadership on job satisfaction and nursing practice compared to transactional leadership addresses the research question. However, it focuses on Saudi nurses and does not include expatriate nurses who may be having different perceptions of leadership styles. Moreover, it was conducted in public hospitals only yet private and military hospitals could give different results due to different administrative practices. No significant Relationship between leadership styles and level of intent to stay: Transformational $(\mathrm{r}=0.08, \mathrm{p}<0.14)$ Transactional $(\mathrm{r}=0.01, \mathrm{p}<0.81)$.

Job satisfaction was moderate $(\mathrm{M} ; 3.69$ (1-6),SD; 49; range (2.28-5.19)

Though not mentioned by the authors, this study used cross sectional design based on the understanding of the methodology process. Reliance on participant's recall can also result in recall or reporting bias.

Table 3. Study 3 (S3)

\begin{tabular}{|c|c|c|c|c|}
\hline $\begin{array}{l}\text { Author, } \\
\text { date }\end{array}$ & \multicolumn{4}{|l|}{ Alshahrani and Baig (2016) } \\
\hline $\begin{array}{l}\text { Study and } \\
\text { Study aim }\end{array}$ & \multicolumn{4}{|c|}{$\begin{array}{l}\text { Context/Location: Critical care units at Aseer Central Hospital (ACH) in the southern region of Saudi } \\
\text { Arabia. } \\
\text { Study Design: Quantitative /cross-sectional study } \\
\text { Study Aim: To evaluate the type of leadership style of the head nurses and its effect on the job satisfaction of } \\
\text { the reporting nurses working in the Critical care units (CCUs). } \\
\text { Theoretical framework: } \text { used theory for conceptualized transformational and transactional }\end{array}$} \\
\hline $\mathbf{S}$ & \multicolumn{4}{|c|}{$\begin{array}{l}\text { Age Range and Gender: Age range was } 22-58 \text { years and } 98 \% \text { were females. } \\
\text { Sampling method: Convenience sample for nursing working in CCUs. } \\
\text { Inclusion criteria: For nurses: Hold registered nursing license, } 6 \text { months experience and working under } \\
\text { supervision of a nurse manager. } \\
\text { Sample size: Sample size calculated. } 160 \text { licensed nurses working in CCUs and } 94 \text { completed questionnaires } \\
\text { were returned ( } 59 \%) \text {. } \\
\text { Ethical issues: Ethical approval and informed consent obtained. }\end{array}$} \\
\hline Varia & \multicolumn{4}{|c|}{$\begin{array}{l}\text { Independent variables: Demographic information and Transformational and transactional leadership styles } \\
\text { Dependent variables: Job satisfaction level }\end{array}$} \\
\hline $\begin{array}{l}\text { me } \\
\text { res }\end{array}$ & \multicolumn{4}{|c|}{$\begin{array}{l}\text { Data Collection: MLQ-5X rater form and JSS questionnaire with demographic questions. questionnaire } \\
\text { collected during nursing education activity days in the CCUs } \\
\text { Validity and Reliability: Content validity: Used previous authors' MLQ and JSS. } \\
\text { Reliability: MLQ-5X and JSS had Cronbach's } \alpha \text { coefficients of } 0.96 \text { and } 0.81 \text { respectively. Questionnaires } \\
\text { pilot tested ( } 3 \text { medical educationaists and } 3 \text { CCU nurses). }\end{array}$} \\
\hline $\begin{array}{l}\text { Analysis } \\
\text { approach }\end{array}$ & \multicolumn{4}{|c|}{$\begin{array}{l}\text { SPSS, Analysis of variance (ANOVA), post Hoc Turkey (HSD), pearson's correlation, Multiple linear } \\
\text { regression analysis, mean (M) and standardized deviation (SD) }\end{array}$} \\
\hline \multirow[t]{5}{*}{ Result } & \multicolumn{4}{|c|}{ Perceived leadership styles in CCUs: } \\
\hline & Leadership styles & $\operatorname{MEAN}(M)=(1-5)$ & $\begin{array}{l}\text { STANDARD } \\
\text { DEVIATION }\end{array}$ & $P$ value \\
\hline & TRANSFORMATIONAL & 3.32 & 2 & 00 \\
\hline & TRANSACTIONAL & 3.85 & 68 & $\mathrm{P}<0.000$ \\
\hline & \multicolumn{4}{|c|}{$\begin{array}{l}\text { Relationship between leadership styles and job satisfaction: The study did not report the overall } \\
\text { transformational style on job satisfaction in terms of statistical significance; however, the majority of the } \\
\text { leaders demonstrated transactional leadership style more than transformational style, and this was associated } \\
\text { with moderate nurses' job satisfaction }(\mathrm{M}=3.40 \text {, between } 3 \text { and } 4 \text { are ambivalence; } \mathrm{SD}=.57) \text {. }\end{array}$} \\
\hline
\end{tabular}




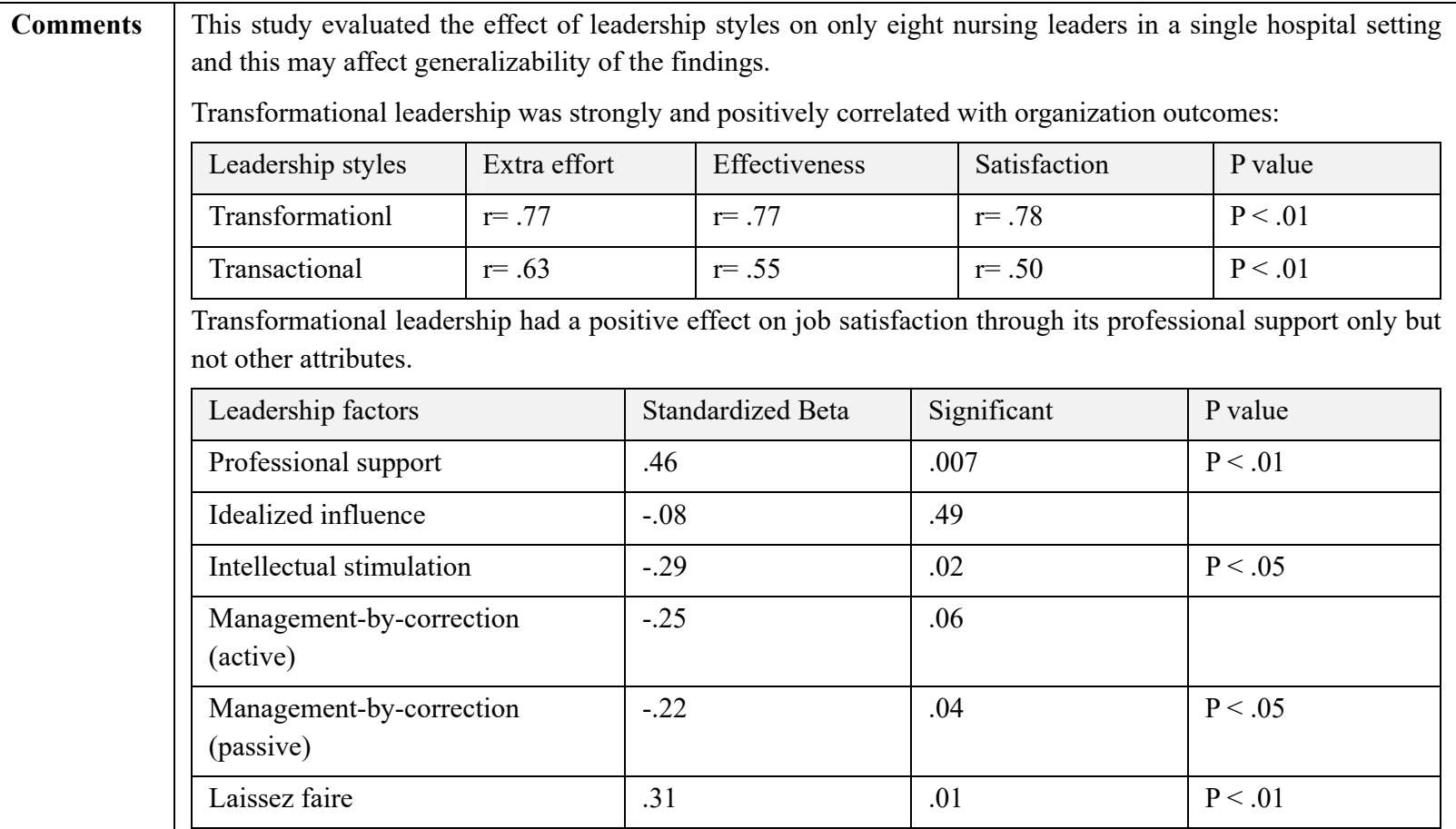

Table4. Study 4 (S4)

\begin{tabular}{|c|c|}
\hline Author, date & Bormann and Abrahamson (2014) \\
\hline $\begin{array}{l}\text { Study and } \\
\text { Study aim }\end{array}$ & $\begin{array}{l}\text { Context/Location: A non-profit acute care hospital in the Southern United States } \\
\text { Study Design: Descriptive correlational } \\
\text { Study Aim: To examine the relationship between staff nurse perception of their nurse manager (NM) } \\
\text { leadership behaviors and their job satisfaction in a hospital on the Magnet journey. } \\
\text { Theoretical framework: used theory for conceptualized transformational, transactional and lassiez faire }\end{array}$ \\
\hline San & $\begin{array}{l}\text { Age Range and Gender: The mean age was } 42.0 \text { years (range between } 26-60 \text { years). No report of gender } \\
\text { distribution. } \\
\text { Sampling method: Purposive sample for nursing working in a hospital seeking for magent status. } \\
\text { Inclusion criteria: Nurses who completed orientation programme, experience at least } 3 \text { months and more } \\
\text { than } 2 \text { months on their current nursing unit. Units with less than } 5 \text { staff nurses were excluded. } \\
\text { Sample size: Sample size not calculated. } 500 \text { nurse managers and staff nurses. } 117 \text { staff nurses completed the } \\
\text { survey (23.4\%) but only } 115 \text { responses were analyzed (23\%). } \\
\text { Ethical issues: Ethical approval and consent obtained. }\end{array}$ \\
\hline Vari & $\begin{array}{l}\text { Independent variables: Demographic information and Transformational, transactional, and } \\
\text { passive-avoidant leadership styles } \\
\text { Dependent variables: Job satisfaction }\end{array}$ \\
\hline & $\begin{array}{l}\text { Data Collection: Self-administered questionnaire, including MLQ 5X Short Form and Abridged Job } \\
\text { Descriptive Index (aJDI) survey and distributed to all nursing units and collected by secure box. } \\
\text { Validity: Content validity: Used previous authors' MLQ and JDI } \\
\text { Reliability: Reported for previous authors (MLQ and JDI had Cronbach's } \alpha \text { coefficients varying from } 0.69 \\
\text { to } 0.83 \text { and } 0.88 \text { to } 0.92 \text { respectively). }\end{array}$ \\
\hline $\begin{array}{l}\text { Analysis } \\
\text { approach }\end{array}$ & SPSS, Pearson's correlation, mean (M) and standardized deviation (SD) and Hierarchical regression analysis \\
\hline
\end{tabular}




\begin{tabular}{|c|c|c|c|}
\hline \multirow[t]{10}{*}{ Result } & \multicolumn{3}{|l|}{ Perceived leadership styles: } \\
\hline & Leadership styles & Mean (0-4) & STANDARD DEVIATION \\
\hline & TRANSFORMATIONAl (TF) & 2.39 & .85 \\
\hline & TRANSACTIONAL (TA) & 2.29 & .70 \\
\hline & PASSIVE AVOIDENT (PA) & 1.59 & 1.04 \\
\hline & \multicolumn{3}{|c|}{ Relationship between leadership styles and job satisfaction: } \\
\hline & Leadership styles & CORRELATION & P VALUE \\
\hline & TRANSFORMATIONAl (TF) & .296 & $\mathrm{P}<0.01$ \\
\hline & TRANSACTIONAL (TA) & .219 & - \\
\hline & PASSIVE AVOIDENT (PA) & -.413 & $\mathrm{P}<0.01$ \\
\hline Comments & \multicolumn{3}{|c|}{$\begin{array}{l}\text { This study was conducted in one hospital on a Magnet journey and this magnet status can affect job } \\
\text { satisfaction, hence the study findings. In addition, varied perceptions in different settings and the low } \\
\text { response rate may affect the generalisability of the findings. Nevertheless, it answers the research question } \\
\text { and objectives and its conduct in developed country makes it useful to this research. } \\
\text { This study found experience for staff nurse to be significantly influenced by leadership behavior: } \\
5 \text { years or less: TF: }(\mathrm{r}=.564, \mathrm{p}<.01) \text {; TA: }(\mathrm{r}=.419, \mathrm{p}<.05) \text {; PA: }(\mathrm{r}=-.687, \mathrm{p}<.05) \text {. There was no significant } \\
\text { influence for } 11 \text { years and above. } \\
\text { Influence of leadership styles on overall job satisfaction: } \mathrm{TF}=(\mathrm{B}=.237, \mathrm{p}<.05) \text {; TA: }(\mathrm{B}=.157) \text {; PA: }(\mathrm{B}= \\
-298, \mathrm{p}<.001) \\
\text { Though not mentioned by the authors, this study used cross sectional design based on the understanding of } \\
\text { the methodology process. }\end{array}$} \\
\hline
\end{tabular}

Table 5. Study 5 (S5)

\begin{tabular}{|c|c|}
\hline $\begin{array}{l}\text { Author, } \\
\text { date }\end{array}$ & Choi et al. (2016) \\
\hline $\begin{array}{l}\text { Study and } \\
\text { study aim }\end{array}$ & $\begin{array}{l}\text { Context/Location: Malaysian two large private and public hospitals. } \\
\text { Study Design: Standardised cross-sectional survey } \\
\text { Study Aim: To explore the relationship among transformational leadership (TF), empowerment, and job } \\
\text { satisfaction. } \\
\text { Theoretical framework: Used conceptual model_(transformational, empoerement and job satisfaction), } \\
\text { conceptualized transformational based on theory transformational leadership style bass (1990) }\end{array}$ \\
\hline Sampling & $\begin{array}{l}\text { Age Range and Gender: The mean age was } 42.0 \text { years and the majority age group was } 26-30 \text { years } \\
\text { representing 59\%. Females accounted for } 92 \% \text { of the respondents. } \\
\text { Sampling method: Purposive. Multistage process: } 326 \text { hospital in Malaysia by } 2014>\text { state of Johor }>10 \\
\text { district in Johar state }>3 \text { public and five private hospitals }>\text { large private and public hospitals in Johor state } \\
\text { selected > all nursing and medical assistants working in the selected hospital. } \\
\text { Inclusion and exclusion criteria: Not reported } \\
\text { Sample size: } 350 \text { nursing staff, including nurses and medical assistants. } 200 \text { valid questionnaires (57.14\%) } \\
\text { Ethical issues: Ethical approval and consent obtained and the work position as well as participants' names } \\
\text { were hidden for confidentiality. }\end{array}$ \\
\hline Variables & $\begin{array}{l}\text { Independent variables: Demographic information and Transformational leadership (TF). } \\
\text { Intermediate variables: Empowerment dimensions } \\
\text { Dependent variables: Job satisfaction as measured by compensation and recognition._ }\end{array}$ \\
\hline $\begin{array}{l}\text { Outcome } \\
\text { measures }\end{array}$ & $\begin{array}{l}\text { Data Collection: A self-administered set of questionnaires for MLQ, empowerment, and job satisfaction } \\
\text { instruments and Collected by the researcher. }\end{array}$ \\
\hline
\end{tabular}




\begin{tabular}{|c|c|c|c|c|}
\hline & \multicolumn{4}{|c|}{$\begin{array}{l}\text { Validity: Content validity: Used previous authors for MLQ and job satisfaction, Expert review and } \\
\text { Used Partial least squares-structural equation modelling (PLS-SEM): Convergent validities and discriminant } \\
\text { validity respectively were } 0.508 \text { and } .713 ; 0.542 \text { and } .736 ; 0.508 \text { and } .713 \text { for transformational leadership, } \\
\text { empowerment and job satisfaction respectively. } \\
\text { Reliability: Used PLS-SEM Composite reliabilities which were } 0.892,0.876 \text { and } 0.804 \text { for transformational } \\
\text { leadership, empowerment and job satisfaction respectively. }\end{array}$} \\
\hline $\begin{array}{l}\text { Analysis } \\
\text { approach }\end{array}$ & \multicolumn{4}{|c|}{$\begin{array}{l}\text { PASW Statistics } 18.0 \text { and SmartPLS } 3.0 \text { programm, descriptive analysis (percentage and frequency) partial } \\
\text { least squares-structural equation modeling (PLS-SEM), Path model, higher order model }\end{array}$} \\
\hline \multirow[t]{8}{*}{ Result } & \multicolumn{4}{|c|}{$\begin{array}{l}\text { Perceived leadership styles in public and private hospital: not reported nursing perception for TF. } \\
\text { Relationship between leadership styles, job satisfaction and empowerment: } \\
\text { Transformational leadership was positively related to job satisfaction as a direct effect or indirectly through } \\
\text { empowerment that, in turn, positively affected job satisfaction. }\end{array}$} \\
\hline & structure model Without mediator & \multicolumn{2}{|l|}{ Path coefficient } & P VALUE \\
\hline & TF AND JOB SATISFACTION & \multicolumn{2}{|l|}{.416} & $\mathrm{P}<.01$ \\
\hline & \multicolumn{2}{|l|}{ Structure model with mediator } & Path coefficient & P VALUE \\
\hline & \multicolumn{2}{|l|}{ TF AND JOB SATISFACTION } & .231 & $\mathrm{P}<.05$ \\
\hline & \multicolumn{2}{|l|}{ TF AND EMPOWERMENT } & .649 & $\mathrm{P}<.01$ \\
\hline & \multicolumn{2}{|c|}{ EMPOWERMENT AND JOB SATISFACTION } & .270 & $\mathrm{P}<.01$ \\
\hline & \multicolumn{2}{|c|}{$\begin{array}{l}\text { TF AND JOB SATISFACTION (MEDICATING } \\
\text { BY EMPOWERMENT) }\end{array}$} & .176 & $\mathrm{P}=.0001$ \\
\hline Comments & \multicolumn{4}{|c|}{$\begin{array}{l}\text { The findings are very useful for this research's investigation of transformational leadership in a broader scope } \\
\text { of both direct and indirect impacts on job satisfaction. Moreover, its coverage of two different hospital } \\
\text { settings of great essence. However, the authors used English language for questionnaire, but ethically same } \\
\text { language should be used to keep it clear for respondents. It also measured only two aspects of job satisfaction } \\
\text { including pay and recognition yet it is affected by various factors. }\end{array}$} \\
\hline
\end{tabular}

Table 6. Study 6 (S6)

\begin{tabular}{|c|c|}
\hline $\begin{array}{l}\text { Author, } \\
\text { date }\end{array}$ & Lin et al. (2015) \\
\hline $\begin{array}{l}\text { Study and } \\
\text { study aim }\end{array}$ & $\begin{array}{l}\text { Context/Location: Twelve hospitals in Taiwan, } 4 \text { hospitals in each type of ownership, including private, } \\
\text { public, and religious. } \\
\text { Study Design: Cross-sectional quantitative } \\
\text { Study Aim: To explore nursing leadership style and its relationship between the mental health outcomes of } \\
\text { nurses. } \\
\text { Theoretical framework: used conceptual model (transformational, supervisor support, job satisfaction, } \\
\text { organization commitement and general health status) }\end{array}$ \\
\hline Sampling & $\begin{array}{l}\text { Age Range and Gender: The mean age was } 30.5 \text { years and majority of the respondents were females. } \\
\text { Sampling method: Convenience sampling from selected hospitals. } \\
\text { Inclusion criteria: one-year experience in the selected hospitals and all nursing graded between basic training } \\
\text { until specialized training and research. } \\
\text { Sample size: } 807 \text { nurses working in each of the selected types of hospital ownership, } 651 \text { valid questionnaires } \\
\text { were completed ( } 80.7 \%) \\
\text { Ethical issues: Ethical approval and signed informed consent . }\end{array}$ \\
\hline Variables & eadership \\
\hline
\end{tabular}




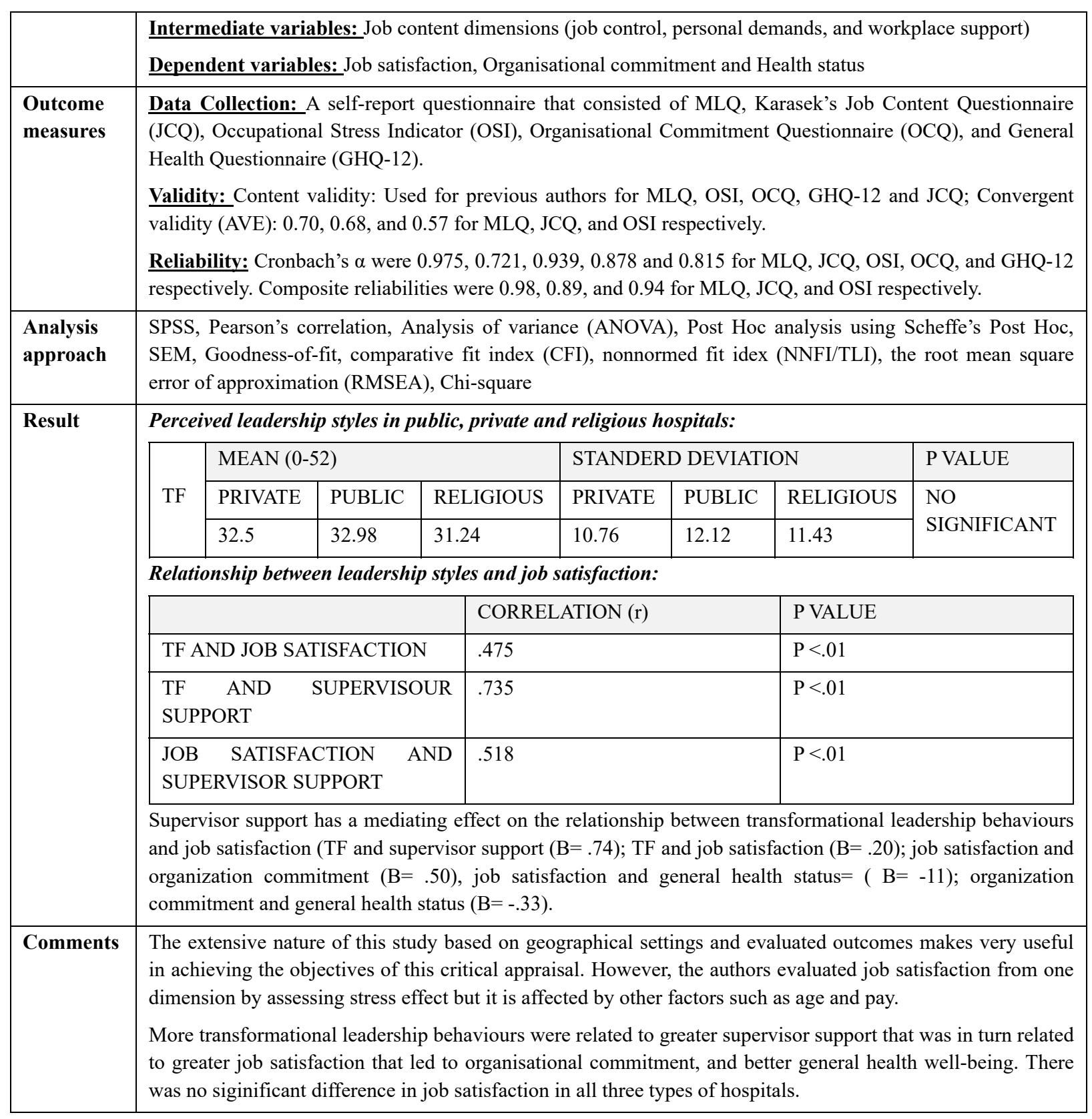


Table 7. Study 7 (S7)

\begin{tabular}{|c|c|}
\hline $\begin{array}{l}\text { Author, } \\
\text { date }\end{array}$ & 7) \\
\hline and & $\begin{array}{l}\text { Context/Location: Ethopia, a specialised hospital in Jimma Town southwest of Addis Ababa. } \\
\text { Study Design: Non-experimental correlational. } \\
\text { Study Aim: To investigate the relationship between leadership styles of nurse managers and nurses' job } \\
\text { satisfaction at Jimma University Specialised Hospital (JUSH). } \\
\text { Theoretical framework: used theory for transformational and transactional, however not clearly } \\
\text { conceptualized in the study. }\end{array}$ \\
\hline & $\begin{array}{l}\text { Age Range and Gender: The age range was } 20-60 \text { years with the majority }(51 \%) \text { falling between } 20-30 \\
\text { years. Females were the majority }(55 \%) \text { of the respondents. } \\
\text { Sampling method: All nurses working in Jimmma hospital. } \\
\text { Inclusion criteria: For nurses: Experience of more than one year, hold diploma or bachelor or master } \\
\text { degree, working under supervision and non-supervisory management position and work full time. } \\
\text { Sample size: } 186 \text { nurses working at JUSH and fulfilled the selection criteria. Used census instead of } \\
\text { sample. } 175 \text { questionnaires were completed and returned (94\%) } \\
\text { Ethical issues: Ethical approval and informed consent obtained. }\end{array}$ \\
\hline & $\begin{array}{l}\text { Independent variables: Demographic data and Transformational, transactional and laissez-faire leadership } \\
\text { dimensions } \\
\text { Dependent variables: Job satisfaction of staff nurses (intrinsic and extrinsic) }\end{array}$ \\
\hline & $\begin{array}{l}\text { Data Collection: Two standardised questionnaires, including MLQ and Minnesota Satisfaction Questionnaire } \\
\text { (MSQ) short form. Collected by three trained diploma nurses after received training for data collection. } \\
\text { Validity and Reliability: Content validity: Used for previous authors for MLQ and MSQ Professional expert } \\
\text { review } \\
\text { Reliability: Cronbach's alpha coefficient for leadership, intrinsic job satisfaction and extrinsic job } \\
\text { satisfaction dimensions were } 0.82,0.90 \text { and } 0.94 \text { respectively. Pilot tested (18 nursing). }\end{array}$ \\
\hline & $\begin{array}{l}\text { SPSS, descriptive statistics ( frequency distribution, percentage, means and standard deviation) and } \\
\text { inferential statistics ( Pearson's correlation, Principal Component Analysis and Multiple Regression) }\end{array}$ \\
\hline Result & $\begin{array}{l}\text { Perceived leadership styles: not reported } \\
\text { Relationship between leadership styles and job satisfaction: not reported total of effect TF on job } \\
\text { satisfaction }\end{array}$ \\
\hline
\end{tabular}




\begin{tabular}{|c|c|c|c|c|c|}
\hline \multirow[t]{11}{*}{ Comments } & \multicolumn{5}{|c|}{$\begin{array}{l}\text { This paper evaluated the outcomes exhaustively making it very important for discussion in this research. The } \\
\text { high reliability of MSQ also makes the study reliable for use in this research. However, the authors used } \\
\text { English language for questionnaire, but ethically same language should be used to keep it clear for } \\
\text { respondents. This study through understanding methodology process used cross sectional and descriptive and } \\
\text { not mention by authors. Transformational leadership dimensions were positively correlated with intrinsic and } \\
\text { extrinsic job satisfaction with inspirational motivation having the strongest relationship. } \\
\text { Intrinsic and extrinsic satisfaction were moderate for sample }(\mathrm{M}=2.72 ; \mathrm{SD}=.71) \text { and low }(\mathrm{M}=1.83 ; \mathrm{SD}=.68) \\
\text { respectively. } \\
\text { Contingent reward and management by-exception (active) of transactional leadership had a similar but weak } \\
\text { correlation while passive and laissez-faire style had a negative relationship. }\end{array}$} \\
\hline & & Intrinsic & Extrinsic & Intrinsic & Extrinsic \\
\hline & $\begin{array}{l}\text { Idealized } \\
\text { (Behaviour) }\end{array}$ & $\mathrm{r}=.31(\mathrm{P}<.01)$ & $\mathrm{r}=.19(\mathrm{P}<.01)$ & $\mathrm{B}=.32(\mathrm{P}<.01)$ & $\mathrm{B}=.19(\mathrm{P}<.05)$ \\
\hline & Idealized influence (Attribute) & $\mathrm{r}=.45(\mathrm{P}<.01)$ & $\mathrm{r}=.27(\mathrm{P}<.01)$ & $\mathrm{B}=.29(\mathrm{P}<.01)$ & $\mathrm{B}=.21(\mathrm{P}<.05)$ \\
\hline & Inspirational Motive & $\mathrm{r}=.51(\mathrm{P}<.01)$ & $\mathrm{r}=.21(\mathrm{P}<.01)$ & $\mathrm{B}=.35(\mathrm{P}<.01)$ & $\mathrm{B}=.22(\mathrm{P}<.01)$ \\
\hline & Intellectual stimulation & $\mathrm{r}=.45(\mathrm{P}<.01)$ & $\mathrm{r}=.32(\mathrm{P}<.01)$ & $\mathrm{B}=.49(\mathrm{P}<.01)$ & $\mathrm{B}=.42(\mathrm{P}<.05)$ \\
\hline & Individual Consideration & $\mathrm{r}=.38(\mathrm{P}<.01)$ & $\mathrm{r}=.25(\mathrm{P}<.01)$ & $\mathrm{B}=.35(\mathrm{P}<.01)$ & $\mathrm{B}=.17(\mathrm{P}<.05)$ \\
\hline & Contingent reward & $\mathrm{r}=.32(\mathrm{P}<.05)$ & $\mathrm{r}=.45(\mathrm{P} .01)$ & $\mathrm{B}=.15(\mathrm{P}<.05)$ & $\mathrm{B}=.39(\mathrm{P}<.01)$ \\
\hline & $\begin{array}{l}\text { Management by Objective } \\
\text { (Active) }\end{array}$ & $\mathrm{r}=.18$ & $\mathrm{r}=.19$ & $\mathrm{~B}=.06(\mathrm{P}<.05)$ & $\mathrm{B}=.08(\mathrm{P}<.05)$ \\
\hline & $\begin{array}{l}\text { Management by Objective } \\
\text { (Passive) }\end{array}$ & $\mathrm{r}=.21$ & $\mathrm{r}=.04$ & $\mathrm{~B}=-.05(\mathrm{P}<.05)$ & $\mathrm{B}=.07(\mathrm{P}<.05)$ \\
\hline & Laissez fair & $\mathrm{r}=.23$ & $\mathrm{r}=.37$ & $\mathrm{~B}=-19(\mathrm{P}<.05)$ & \begin{tabular}{ll|}
$\mathrm{B}=$ & -.15 \\
$(\mathrm{P}<.05)$ &
\end{tabular} \\
\hline
\end{tabular}

Table 8. Study 8 (S8)

\begin{tabular}{|c|c|}
\hline $\begin{array}{l}\text { Author, } \\
\text { date }\end{array}$ & al. (2012) \\
\hline $\begin{array}{l}\text { Study and } \\
\text { Study aim }\end{array}$ & $\begin{array}{l}\text { Context/Location: A tertiary hospital in Harbin, People's Republic of China. } \\
\text { Study Design: Descriptive correlation survey } \\
\text { Study Aim: To describe the relationship between the transformational leadership of nurse managers and the } \\
\text { job satisfaction of clinical registered nurses. } \\
\text { Theoretical framework: used Kouzes and Posner's leadership practice model consist of : challenging the } \\
\text { process, inspiring a shared vision, enabling others to act, modelling the way and encouraging the heart. } \\
\text { (Kouzes and Posner, 1995) }\end{array}$ \\
\hline & $\begin{array}{l}\text { Age Range and Gender: Majority of the participants was } 20-30 \text { years }(72.69 \%) \text { and females represented } \\
97.9 \% \text { of the participants. } \\
\text { Sampling method: Stratified random sampling } \\
\text { Inclusion criteria: for nursing was working experience more than one years and hold national nursing } \\
\text { license. } \\
\text { Sample size: Sample size calculated. } 250 \text { clinical registered nurses working in nine clinical nursing } \\
\text { departments. } 238 \text { valid questionnaires were analysed (95.2\%) } \\
\text { Ethical issues: Ethical approval and informed consent obtained. }\end{array}$ \\
\hline Variables & $\begin{array}{l}\text { Independent variables: Demographic data and Transformational leadership style. } \\
\text { Dependent variables: Job satisfaction level }\end{array}$ \\
\hline Outcome & ire package of demographic data, the Chine version of the Leadership Practice \\
\hline
\end{tabular}




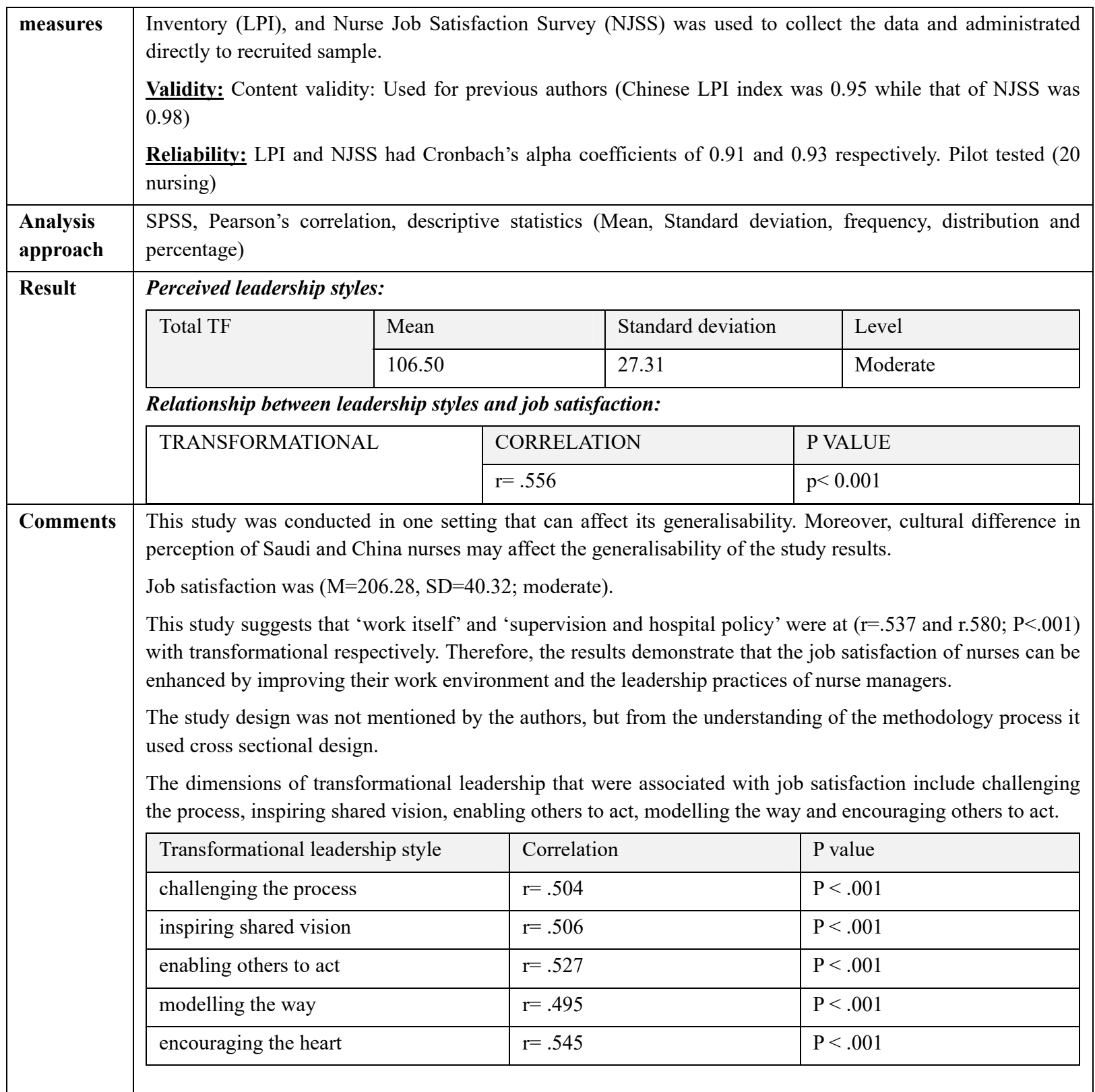

\section{Copyrights}

Copyright for this article is retained by the author(s), with first publication rights granted to the journal.

This is an open-access article distributed under the terms and conditions of the Creative Commons Attribution license (http://creativecommons.org/licenses/by/4.0/). 